2008

\title{
Interactions Between Changing pCO2, N2 Fixation, and Fe Limitation in the Marine Unicellular Cyanobacterium Crocosphaera
}

Fei-Xue Fu

Margaret R. Mulholland

Old Dominion University, mmulholl@odu.edu

Nathan S. Garcia

Aaron Beck

Mark E. Warner

See next page for additional authors

Follow this and additional works at: https://digitalcommons.odu.edu/oeas_fac_pubs

Part of the Biogeochemistry Commons, Cell Biology Commons, Ecology and Evolutionary Biology Commons, Marine Biology Commons, Microbiology Commons, and the Oceanography Commons

\section{Repository Citation}

Fu, Fei-Xue; Mulholland, Margaret R.; Garcia, Nathan S.; Beck, Aaron; Warner, Mark E.; Sañudo, Sergio A.; and Hutchins, David A., "Interactions Between Changing pCO2, N2 Fixation, and Fe Limitation in the Marine Unicellular Cyanobacterium Crocosphaera" (2008). OEAS Faculty Publications. 167.

https://digitalcommons.odu.edu/oeas_fac_pubs/167

\section{Original Publication Citation}

Fu, F.-X., Mulholland, M.R., Garcia, N.S., Beck, A., Bernhardt, P.W., Warner, M.E., ... Hutchins, D.A. (2008). Interactions between changing $\mathrm{pCO}_{2}, \mathrm{~N}_{2}$ fixation, and Fe limitation in the marine unicellular cyanobacterium Crocosphaera. Limnology and Oceanography, 53(6), 2472-2484. doi: 10.4319/lo.2008.53.6.2472 
Authors

Fei-Xue Fu, Margaret R. Mulholland, Nathan S. Garcia, Aaron Beck, Mark E. Warner, Sergio A. Sañudo, and David A. Hutchins 


\title{
Interactions between changing $\mathrm{pCO}_{2}, \mathrm{~N}_{2}$ fixation, and $\mathrm{Fe}$ limitation in the marine unicellular cyanobacterium Crocosphaera
}

\section{Fei-Xue Fu ${ }^{1}$}

Department of Biological Sciences, University of Southern California, 3616 Trousdale Parkway, Los Angeles, California 90089

\section{Margaret R. Mulholland}

Department of Ocean, Earth and Atmospheric Sciences, Old Dominion University, 4600 Elkhorn Avenue, Norfolk, Virginia 23529

\section{Nathan S. Garcia}

Department of Biological Sciences, University of Southern California, 3616 Trousdale Parkway, Los Angeles, California 90089

\section{Aaron Beck}

Max-Planck-Institut für Marine Mikrobiologie, Celsius Str. 1, D-28359 Bremen, Germany

\section{Peter W. Bernhardt}

Department of Ocean, Earth and Atmospheric Sciences, Old Dominion University, 4600 Elkhorn Avenue, Norfolk, Virginia 23529

\section{Mark E. Warner}

College of Marine and Earth Studies, University of Delaware, 700 Pilottown Road, Lewes, Delaware 19958

\section{Sergio A. Sañudo-Wilhelmy and David A. Hutchins}

Department of Biological Sciences, University of Southern California, 3616 Trousdale Parkway, Los Angeles, California 90089

\begin{abstract}
We examined the physiological responses of steady-state iron (Fe)-replete and Fe-limited cultures of the biogeochemically critical marine unicellular diazotrophic cyanobacterium Crocosphaera at glacial (19 Pa; $190 \mathrm{ppm}$ ), current (39 Pa; $380 \mathrm{ppm}$ ), and projected year 2100 (76 Pa; 750 ppm) $\mathrm{CO}_{2}$ levels. Rates of $\mathrm{N}_{2}$ and $\mathrm{CO}_{2}$ fixation and growth increased in step with increasing partial pressure of $\mathrm{CO}_{2}\left(\mathrm{pCO}_{2}\right)$, but only under Fe-replete conditions. $\mathrm{N}_{2}$ and carbon fixation rates at $75 \mathrm{~Pa} \mathrm{CO}_{2}$ were 1.4-1.8-fold and 1.2-2.0-fold higher, respectively, relative to those at present day and glacial $\mathrm{pCO}_{2}$ levels. In Fe-replete cultures, cellular $\mathrm{Fe}$ and molybdenum quotas varied threefold and were linearly related to $\mathrm{N}_{2}$ fixation rates and to external $\mathrm{pCO}_{2}$. However, $\mathrm{N}_{2}$ fixation and trace metal quotas were decoupled from $\mathrm{pCO}_{2}$ in Fe-limited Crocosphaera. Higher $\mathrm{CO}_{2}$ and $\mathrm{Fe}$ concentrations both resulted in increased cellular pigment contents and affected photosynthesis vs. irradiance parameters. If these results also apply to natural Crocosphaera populations, anthropogenic $\mathrm{CO}_{2}$ enrichment could substantially increase global oceanic $\mathrm{N}_{2}$ and $\mathrm{CO}_{2}$ fixation, but this effect may be tempered by Fe availability. Possible biogeochemical consequences may include elevated inputs of new nitrogen to the ocean and increased potential for $\mathrm{Fe}$ and/or phosphorus limitation in the future high- $\mathrm{CO}_{2}$ ocean, and feedbacks to atmospheric $\mathrm{pCO}_{2}$ in both the near future and over glacial to interglacial timescales.
\end{abstract}

${ }^{1}$ Corresponding author (ffu@usc.edu).

\section{Acknowledgments}

The authors thank Jon Sharp for assistance with dissolved inorganic carbon analyses and Bill Sunda and an anonymous reviewer for helpful comments.

Grant support was provided by National Science FoundationOcean Sciences (NSF-OCE) grants 0741412 and 0722337 to D.A.H., NSF-OCE 0136367 to M.R.M., NSF-OCE 0722435 to M.E.W., and NOAA Global Carbon Cycle Program (GC04-354) to S.S-W.
By the end of this century, $\mathrm{CO}_{2}$ levels in the atmosphere and in surface seawater will roughly double, to $70-75 \mathrm{~Pa}$ (IPCC 2007). In the context of this anticipated doubling of the partial pressure of $\mathrm{CO}_{2}\left(\mathrm{pCO}_{2}\right)$, some culture and field studies have indicated that growth and carbon fixation by marine phytoplankton may increase (Kim et al. 2006; Fu et al. 2007; Hutchins et al. 2007). Anthropogenically driven changes in $\mathrm{CO}_{2}$ availability may thus exert a strong control on algal physiology, nutrient cycling, and ecological interactions. 
Experiments with natural phytoplankton communities indicate that elevated $\mathrm{CO}_{2}$ could result in increased phytoplankton primary production in the open ocean (Hein and Sand-Jensen 1997) or in changes in competitive interactions among major marine phytoplankton groups (Tortell et al. 2002; Hare et al. 2007). Laboratory studies have shown that changes in $\mathrm{CO}_{2}$ concentrations can result in species-specific modifications in cellular carbon acquisition pathways (Raven 1997; Tortell et al. 2000; Burkhardt et al. 2001) and elemental ratios (Tortell et al. 2000; Fu et al. 2007; Hutchins et al. 2007).

Many cyanobacteria possess active carbon concentrating mechanisms $(\mathrm{CCMs})$ that facilitate $\mathrm{HCO}_{3}^{-}$or $\mathrm{CO}_{2}$ transport and interconversion in order to increase $\mathrm{CO}_{2}$ concentration near ribulose-1,5-bisphosphate carboxylase oxygenase (RUBISCO). These CCMs can support rapid growth even at low external dissolved inorganic carbon (DIC) concentrations (Badger et al. 2006). These active DIC transport processes, however, involve substantial energetic and metabolic costs. Consequently, it has been speculated that increased $\mathrm{CO}_{2}$ availability could potentially reduce the allocation of energy or nutrients needed for carbon acquisition (Hutchins et al. 2007).

Recently several studies using cultures of the diazotrophic cyanobacterium Trichodesmium demonstrated that $\mathrm{CO}_{2}$ availability controls nitrogen (N) and carbon (C) fixation rates and elemental ratios in this biogeochemically critical genus (Hutchins et al. 2007; Levitan et al. 2007; Ramos et al. 2007). These results indicate that Trichodesmium, which is thought to provide up to $50 \%$ of new nitrogen in the oligotrophic gyres (Karl et al. 2002), is carbon limited at present-day $\mathrm{pCO}_{2}$. By the end of this century $\mathrm{CO}_{2}$ enrichment could substantially increase $\mathrm{N}_{2}$ and $\mathrm{CO}_{2}$ fixation by Trichodesmium, fundamentally altering the current marine $\mathrm{N}$ and $\mathrm{C}$ cycles and providing a possible negative feedback on atmospheric $\mathrm{pCO}_{2}$. Downregulation of Trichodesmium $\mathrm{N}_{2}$ fixation at low glacial $\mathrm{pCO}_{2}$ levels could also play a pivotal role in global climatic shifts over longer periods, by reducing the inputs of new $\mathrm{N}$ that drive atmospheric $\mathrm{CO}_{2}$ sequestration via the oceanic biological pump (Hutchins et al. 2007).

Although Trichodesmium has long been recognized as a dominant contributor to oceanic diazotrophy (Capone et al. 1997), recent evidence shows that total global marine $\mathrm{N}_{2}$ fixation by unicellular $\mathrm{N}_{2}$-fixing cyanobacteria probably equals or exceeds that of Trichodesmium (Montoya et al. 2004). Unicellular diazotrophs such as Crocosphaera watsonii are a widespread diazotrophic group that can fix $\mathrm{N}_{2}$ at high rates, and, hence, they can provide a substantial fraction of new $\mathrm{N}$ where they occur (Montoya et al. 2004; Falcon et al. 2005; Mulholland 2007).

In view of the new evidence for $\mathrm{CO}_{2}$ control of carbon and $\mathrm{N}_{2}$ fixation by Trichodesmium, the question arises as to whether other diazotrophic cyanobacteria exhibit similar responses to $\mathrm{CO}_{2}$. In the non-nitrogen fixing unicellular cyanobacteria Synechococcus and Prochlorococcus, the responses of two common strains are quite different; there is a growth response of the former to changing $\mathrm{pCO}_{2}$, but not of the latter (Fu et al. 2007). Thus, it is entirely possible that unicellular $\mathrm{N}_{2}$-fixers might exhibit a unique set of physiological changes in response to changing $\mathrm{pCO}_{2}$. Despite the growing body of research investigating global change effects on marine phytoplankton, including diatoms (Burkhardt and Riebesell 1997; Tortell et al. 2002), cyanobacteria ( $\mathrm{Fu}$ et al. 2007; Hutchins et al. 2007), coccolithophores (Feng et al. 2008), and harmful bloom flagellates (Fu et al. 2008), the effects of changing seawater $\mathrm{pCO}_{2}$ on unicellular $\mathrm{N}_{2}$-fixing cyanobacteria have not been examined.

Much recent research has focused on limiting factors for diazotrophic growth in the current ocean, particularly on the influences of potentially limiting nutrients such as iron (Fe) and phosphorus (P) (Sañudo-Wilhelmy et al. 2001; Mills et al. 2004; $\mathrm{Fu}$ et al. 2005a). Other studies have examined the effects of physical factors such as temperature and light availability (Bell and $\mathrm{Fu} 2005$; Mulholland and Bernhardt 2005; Hutchins et al. 2007). Anthropogenic global change is of course by no means limited to $\mathrm{pCO}_{2}$ increases, and far-reaching, comprehensive changes in the global environment are virtually certain to affect all of these other potential $\mathrm{N}_{2}$ fixation-controlling variables as well. Rising sea surface temperature, increased stratification, shallower mixed layers, decreased vertical nutrient fluxes, and changing aeolian $\mathrm{Fe}$ inputs will all be likely consequences of near-future global change effects on the ocean (Sarmiento et al. 2004; Bopp et al. 2001; Boyd and Doney 2002). For instance, some projections indicate that future $\mathrm{Fe}$ supplies could increase to parts of the open ocean as a result of either accelerating human-induced desertification (Takeda and Tsuda 2005) or to deposition of anthropogenic fossil fuel aerosols (Sedwick et al. 2007). Although Fe limitation is now widely recognized as a major constraint on marine $\mathrm{N}_{2}$ fixation (Kustka et al. 2003), how global change-driven shifts in Fe supply will interact with rising $\mathrm{pCO}_{2}$ to influence the future $\mathrm{N}$ cycle is currently unknown.

A large body of existing literature on $\mathrm{N}_{2}$ fixation has focused on understanding how Fe availability could control growth and $\mathrm{N}_{2}$ fixation by Trichodesmium (Rueter et al. 1990; Berman-Frank et al. 2001; Fu and Bell 2003). Previous culture studies on Trichodesmium have demonstrated that photosynthesis, growth, and $\mathrm{N}_{2}$ fixation were stimulated by the addition of $\mathrm{Fe}$ (Fu and Bell 2003), and modeling work by Berman-Frank et al. (2001) indicates that $\mathrm{Fe}$ availability restricts $\mathrm{N}_{2}$ fixation by Trichodesmium in $75 \%$ of the global ocean. Fe requirements and cellular $\mathrm{Fe}$ quotas from both cultures and natural populations of Trichodesmium have been estimated (Berman-Frank et al. 2001; Kustka et al. 2003).

Past studies of the genus Crocosphaera have included expression assays of genes responsible for $\mathrm{N}_{2}$ fixation and $\mathrm{P}$ scavenging (Dyhrman and Haley 2006) and P uptake kinetics experiments (Falcon et al. 2005). However, to date, relatively little work has been done to determine the $\mathrm{Fe}$ requirements of unicellular diazotrophic cyanobacteria (Tuit et al. 2004; Berman-Frank et al. 2007). Based on the results of natural community incubation experiments, Mills et al. (2004) suggested that Fe limitation (or colimitation, along with $\mathrm{P}$ ) restricts the $\mathrm{N}_{2}$ fixation of unicellular diazotrophs in the tropical North Atlantic. 
Currently there is little published information on the $\mathrm{Fe}$ quotas and physiology of Crocosphaera (Tuit et al. 2004) and none at all that concerns how Fe availability could interact with changing $\mathrm{pCO}_{2}$ and potential consequent changes in $\mathrm{N}_{2}$ fixation rates.

In fact, despite the increasing amount of attention that has been devoted to the responses of Trichodesmium to growth-limiting nutrients and to changes in $\mathrm{pCO}_{2}$, nothing is known about their combined effects on $\mathrm{N}_{2}$ fixation and growth of any other marine diazotrophs. The purpose of this study was to fill this gap and gather basic information on the growth, photosynthetic physiology, elemental ratios, and $\mathrm{Fe}$ quotas of a Sargasso Sea isolate of the unicellular $\mathrm{N}_{2}$-fixer Crocosphaera (Dyhrman and Haley 2006) under conditions of glacial era, present day, and projected year $2100 \mathrm{pCO}_{2}$. We examined all of these $\mathrm{pCO}_{2}$ treatments under both Fe-limited (present day scenario) or Fe-replete (glacial and projected scenarios) growth conditions. The effect of variable $\mathrm{pCO}_{2}$ on molybdenum (Mo) quotas, another metal required for $\mathrm{N}$ fixation, was also investigated.

\section{Methods}

Cultures and growth conditions-Experiments used Crocosphaera watsonii WH8501, which is genetically nearly identical ( $>99 \%$ identity) to sequences found in North Pacific metagenomic collections (Zehr et al. 2007). Stock and experimental cultures were grown at $28^{\circ} \mathrm{C}$ in $0.2 \mu \mathrm{m}-$ filtered, microwave-sterilized surface Sargasso seawater, which lacked added fixed $\mathrm{N}$ but was enriched with AQUIL levels of phosphate and trace nutrients (Morel et al. 1979). Fe stock was chelated with ethylenediaminetetraacetic acid (EDTA) before being added to the medium at final concentrations of $5.0 \mu \mathrm{mol} \mathrm{L}{ }^{-1}$ EDTA and $0.45 \mu \mathrm{mol}$ $\mathrm{L}^{-1} \mathrm{Fe}$, respectively. Light was provided on a $12: 12$ dark: light cycle using cool white fluorescent bulbs at $80 \mu \mathrm{mol}$ photons $\mathrm{m}^{-2} \mathrm{~s}^{-1}$.

Experimental set-up - Semicontinuous culturing methods were used in order to measure $\mathrm{Fe}$ and $\mathrm{pCO}_{2}$ effects during acclimated, steady-state growth (Fu et al. 2007; Hutchins et al. 2007). For all experiments, final sampling occurred once steady-state growth was obtained for each growth condition. Cultures were deemed to be at steady state when there were no significant differences in growth rates $(p>0.05)$ for at least seven generations. Experiments were conducted in triplicate 1-liter acid-washed and microwaved polycarbonate bottles containing 0.9 liters of medium.

Semicontinuous cultures were diluted every $2 \mathrm{~d}$ with medium that was previously adjusted to the appropriate temperature and $\mathrm{pCO}_{2}$. Each bottle was diluted individually based on the cell count-derived growth rate calculated for that bottle, allowing each culture to independently reach its steady-state growth rate under a given experimental treatment. Samples from each culture bottle were always taken at the same time in the diel cycle (Tuit et al. 2004), between $09: 00 \mathrm{~h}$ and 10:00 $\mathrm{h}$ in the morning, to measure cell density and, thus, to determine changes in growth rate.
The water for the experimental culture medium was the same Sargasso Sea seawater used for stock cultures, but it was collected using a shipboard trace metal-clean Teflon diaphragm pump system coupled to an acid-washed in-line $0.2-\mu \mathrm{m}$ cartridge filter. The water was stored in the dark at $4{ }^{\circ} \mathrm{C}$ in acid-washed polycarbonate carboys until use. All medium handling, culturing, and manipulation used careful trace metal-clean methods under class 100 conditions (Hutchins et al. 1998; Fu and Bell 2003; Hare et al. 2007).

Added Fe concentrations were 450 and $10 \mathrm{nmol} \mathrm{L}^{-1}$ for the Fe-replete and Fe-limited cultures, respectively. Within each $\mathrm{Fe}$ condition, triplicate bottles were equilibrated at three different $\mathrm{CO}_{2}$ concentrations: $19 \mathrm{~Pa}, 39 \mathrm{~Pa}$, and $76 \mathrm{~Pa}$. These concentrations were chosen to simulate a range of $\mathrm{pCO}_{2}$ spanning glacial atmospheric levels (Petit et al. 1999), current concentrations, and the values predicted to occur by the end of this century (IPCC 2007). Seawater media was gently bubbled with commercially prepared air and $\mathrm{CO}_{2}$ mixtures to achieve targeted $\mathrm{CO}_{2}$ concentrations (Scott Gas). In-line high-efficiency particulate air filters were used to avoid $\mathrm{Fe}$ contamination from particles in the gas tanks or lines. $\mathrm{CO}_{2}$ equilibration was monitored daily by measuring $\mathrm{pH}$ and DIC. The $\mathrm{pH}$ under steady-state growth conditions was $\sim 8.5$ at low $\mathrm{pCO}_{2}, \sim 8.1$ at ambient $\mathrm{pCO}_{2}$, and $\sim 7.9$ at elevated $\mathrm{pCO}_{2}$. In general, total DIC concentrations were $\sim 6 \%$ and $\sim 14 \%$ higher in the $76-\mathrm{Pa}$ $\mathrm{pCO}_{2}$ treatments than in the $39-\mathrm{Pa} \mathrm{pCO}_{2}$ and $19-\mathrm{Pa} \mathrm{pCO}_{2}$ treatments, respectively (data not shown).

Analytical methods- $\mathrm{N}_{2}$ fixation rates were estimated during the dark period using both acetylene reduction and ${ }^{15} \mathrm{~N}_{2}$ incorporation methods, as described previously in Hutchins et al. (2007) and Mulholland and Bernhardt (2005). Samples for the analysis of particulate organic carbon (POC), particulate organic nitrogen $(\mathrm{PON})$, and particulate organic phosphorus (POP) were collected onto precombusted $\left(450^{\circ} \mathrm{C}\right.$ for $\left.5 \mathrm{~h}\right) 25-\mathrm{mm} \mathrm{GF} / \mathrm{F}$ glass-fiber filters under low vacuum. POC and PON were analyzed on a 440 Elemental Analyzer following the protocol of $\mathrm{Fu}$ et al. (2007). The POP measurement is described in detail in $\mathrm{Fu}$ et al. (2005b). Cells were counted in a hemacytometer using epifluorescence microscopy.

Short-term production vs. irradiance (P-E) curves and 24-h primary production measurements under experimental conditions were conducted as described in Fu et al. (2008). Photosynthetic rates for the P-E curves were measured by incubating $5-\mathrm{mL}$ culture samples in $7-\mathrm{mL}$ vials with $0.1 \mu \mathrm{Ci}$ $\mathrm{mL}^{-1}{ }^{14} \mathrm{C}$ sodium bicarbonate at $28^{\circ} \mathrm{C}$ for $30 \mathrm{~min}$. The incubations were terminated by rapid filtration directly after the cells were killed with glutaraldehyde. Irradiance was provided by a photosynthetron (Composite High Pressure Technologies) and ranged from 10 to $900 \mu \mathrm{mol}$ photons $\mathrm{m}^{-2} \mathrm{~s}^{-1}$. Duplicate vials for each treatment were wrapped in aluminum foil to estimate any dark uptake. All ${ }^{14} \mathrm{C}$ uptake rates were corrected for dark uptake. Cellnormalized data were fitted to the equation of Platt et al. (1980) using the curve-fitting program in SigmaPlot to obtain the photosynthetic parameters. These included photosynthetic efficiency, $\alpha$ [ng C (cell) $)^{-1} \mathrm{~h}^{-1}(\mu \mathrm{mol}$ quanta $\left.\mathrm{m}^{-2} \mathrm{~s}^{-1}\right)^{-1}$, and the maximum cell-specific $\mathrm{C}$ 
fixation rate, $\mathrm{P}_{\mathrm{Bmax}}\left[\mathrm{ng} \mathrm{C}\right.$ (cell) ${ }^{-1} \mathrm{~h}^{-1}$. $\mathrm{E}_{\mathrm{k}}$, the light saturation point and index of light adaptation, was calculated as $\mathrm{P}_{\mathrm{Bmax}} / \alpha$. Primary production was measured in triplicate using 24-h incubations with $\mathrm{H}^{14} \mathrm{CO}_{3}$ under the appropriate experimental growth conditions for each treatment $(\mathrm{Fu}$ et al. 2007). All $\mathrm{C}$-fixation rates were calculated using initial experimental DIC concentrations and cell numbers for each treatment. For the analysis of total dissolved inorganic $\mathrm{C}, 25-\mathrm{mL}$ samples from each bottle were preserved with $200 \mu \mathrm{L} 5 \% \mathrm{HgCl}_{2} \mathrm{~L}^{-1}$ and stored at $4{ }^{\circ} \mathrm{C}$ until analysis in triplicate. Details of the DIC analyses are given in Fu et al. (2007).

The cyanobacterial accessory pigments phycoerythrin (PE) and phycocyanin (PC) were determined from 50-70$\mathrm{mL}$ samples filtered through $\mathrm{GF} / \mathrm{F}$ glass-fiber filters and then immediately placed in the freezer at $-80^{\circ} \mathrm{C}$ until analysis. Frozen sample filters were cut into strips and placed into a $10-\mathrm{mL}$ all-glass tissue grinder with $3 \mathrm{~mL}$ of $50 \mathrm{mmol} \mathrm{L}-1$ phosphate buffer ( $\mathrm{pH}$ 7.0) containing $2 \mathrm{mg}$ $\mathrm{mL}^{-1}$ lysozyme. Each filter was thoroughly homogenized and then the homogenates were immersed in an ice bath and sonicated with a micro-tip sonication probe for $1 \mathrm{~min}$ to rupture the cell wall and increase the extraction efficiency. After sonication, the samples were kept in the dark at $4{ }^{\circ} \mathrm{C}$ for $1 \mathrm{~h}$ and then filtered through a $0.45-\mu \mathrm{m}$ membrane filter. The filtrate was then withdrawn, and concentrations of PE and PC were determined using a spectrophotometer. Quantitative estimations of PE per cell were determined using the molar extinction coefficient from Wyman (1992). PC concentrations were determined spectrophotometrically as in Fu et al. (2007). GF/F glass-fiber filter samples for chlorophyll $a(\mathrm{Chl} a)$ analysis were stored frozen at $-20^{\circ} \mathrm{C}$. Chlorophyll was extracted in the dark for $24 \mathrm{~h}$ in $6 \mathrm{~mL}$ of a mixture of ice-cold $90 \%$ acetone and $10 \%$ water. The extracted Chl $a$ was measured fluorometrically in duplicate on a Turner Designs 10AU fluorometer.

Trace metal quota measurements-Samples for analysis of cellular $\mathrm{Fe}$ and $\mathrm{Mo}$ quotas were filtered onto acidwashed $0.2-\mu \mathrm{m}$ polycarbonate filters under class 100 conditions using trace metal-clean handling and filtering techniques (Frew et al. 2006). The samples were rinsed with oxalate reagent to remove surface-adsorbed $\mathrm{Fe}$, according to the method of Tovar-Sanchez et al. (2003); this was followed by three rinses with trace metal-clean $0.2 \mu \mathrm{m}-$ filtered seawater. Inductively coupled plasma mass spectrometry (ICPMS) was used for the determination of trace metals and P. The procedures for the filter digestions and trace metal analyses were those described in SañudoWilhelmy et al. (2001), with minor modifications. Briefly, the filter samples were digested with $1.5 \mathrm{~mL}$ concentrated Q-HCL, $0.5 \mathrm{~mL}$ of concentrated Q- $\mathrm{HNO}_{3}$, and $25 \mu \mathrm{L}$ Q$\mathrm{HF}$ at room temperature for 2 weeks initially, and then for an additional 4 months. The second 4-month digestion was carried out to assess whether additional cellular metals were solubilized by the long-term acid digestion. Trace element concentrations of the digested samples were determined twice, the first time immediately after the 2week acid digestion and a second time after the 4-month digestion. Procedural blank filters for each treatment were carried through the filtration, rinsing, digestion, incubation, and analysis processes, and these blank values were subtracted from measured values.

Statistical analysis-Effects of the two independent variables $\mathrm{pCO}_{2}$ and $\mathrm{Fe}$ on each dependent variable (including growth rates, $\mathrm{N}_{2}$ fixation rates, photosynthetic parameters, cell quotas, and elemental ratios) in the experiments were assessed using two-way ANOVA to detect two-way interactions (Systat software). This test is based on the method of Zar (1999). Differences between treatment groups were determined using a Tukey multiple comparisons test. Differences were termed significant when $p<0.05$. Three replicate bottles for every treatment were each sampled for each analysis, so for all data presented, $n$ $=3$. There are six (two $\times$ three) combinations of the two factors; therefore, there are a total of $N=18$ data in this experiment.

\section{Results}

Growth rates-In Fe-replete cultures, growth rates increased with increasing $\mathrm{CO}_{2}$ concentrations (Fig. 1A). Growth rates in the 19-Pa treatment were significantly lower than in the other two treatments $\left(F_{1,12}=74.36, p=\right.$ $\left.0.00005 ; F_{1,12}=39.2, p=0.0005\right)$. They were also slightly higher in the 76- $\mathrm{Pa} \mathrm{CO}_{2}$ treatment than in the $39-\mathrm{Pa} \mathrm{CO}_{2}$ treatment, although these differences were not significant $\left(F_{1,12}=2.3, p=0.3\right)$.

As expected, the growth rates of Fe-limited cultures (Fig. 1B) were significantly lower $\left(\sim 50-60 \%, F_{1,12}=248, p\right.$ $=0.0005)$ than those of Fe-replete cultures (Fig. 1A) grown under the same $\mathrm{CO}_{2}$ conditions. As in the Fe-replete cultures, there was no significant difference between the 76$\mathrm{PaCO}$ treatment and the $39-\mathrm{Pa} \mathrm{CO}_{2}$ treatment for the Felimited treatments $\left(F_{1,12}=2.3, p=0.3\right)$. Growth rates in the Fe-limited 19-Pa treatment were significantly lower than those in the 76-Pa treatment $\left(F_{1,12}=33, p=0.003\right)$, but they were not significantly different from those in the 39-Pa treatment $\left(F_{1,12}=1.0, p=0.5\right)$.

$N_{2}$ fixation-Elevated $\mathrm{CO}_{2}$ stimulated the rates of $\mathrm{N}_{2}$ fixation in Fe-replete cultures, with a progressive increase in fixation rates across the three $\mathrm{pCO}_{2}$ treatments (Fig. 2A). C-normalized $\mathrm{N}_{2}$ fixation rates in the $76-\mathrm{Pa}$ treatment were 1.4-fold and 1.8-fold higher than in the 39$\mathrm{Pa}$ and 19-Pa treatments, respectively $\left(F_{1,12}=30.2, p=\right.$ $0.03 ; F_{1,12}=513, p=0.002$ ). The cultures grown at 39-Pa $\mathrm{CO}_{2}$ also exhibited significantly higher $\mathrm{N}_{2}$ fixation rates $\left(\sim 1.3\right.$ fold, $\left.F_{1,12}=18.6, p=0.05\right)$ compared with the $19-\mathrm{Pa}$ treatment. In contrast, the rates of $\mathrm{N}_{2}$ fixation by $\mathrm{Fe}$ limited cultures were much lower and relatively constant with increasing $\mathrm{CO}_{2}$ concentrations $\left(F_{1,12}=3.2, p=0.15\right.$; Fig. 2B). For both Fe-replete and Fe-limited cultures, $\mathrm{N}_{2}$ fixation rates calculated from acetylene reduction measurements showed the same trends as those obtained using ${ }^{15} \mathrm{~N}_{2}$ incorporation (data not shown).

It is not surprising to find that in general, $\mathrm{N}_{2}$ fixation rates were higher in Fe-replete cultures than in Fe-limited cultures. With regard to the interaction between $\mathrm{Fe}$ and 

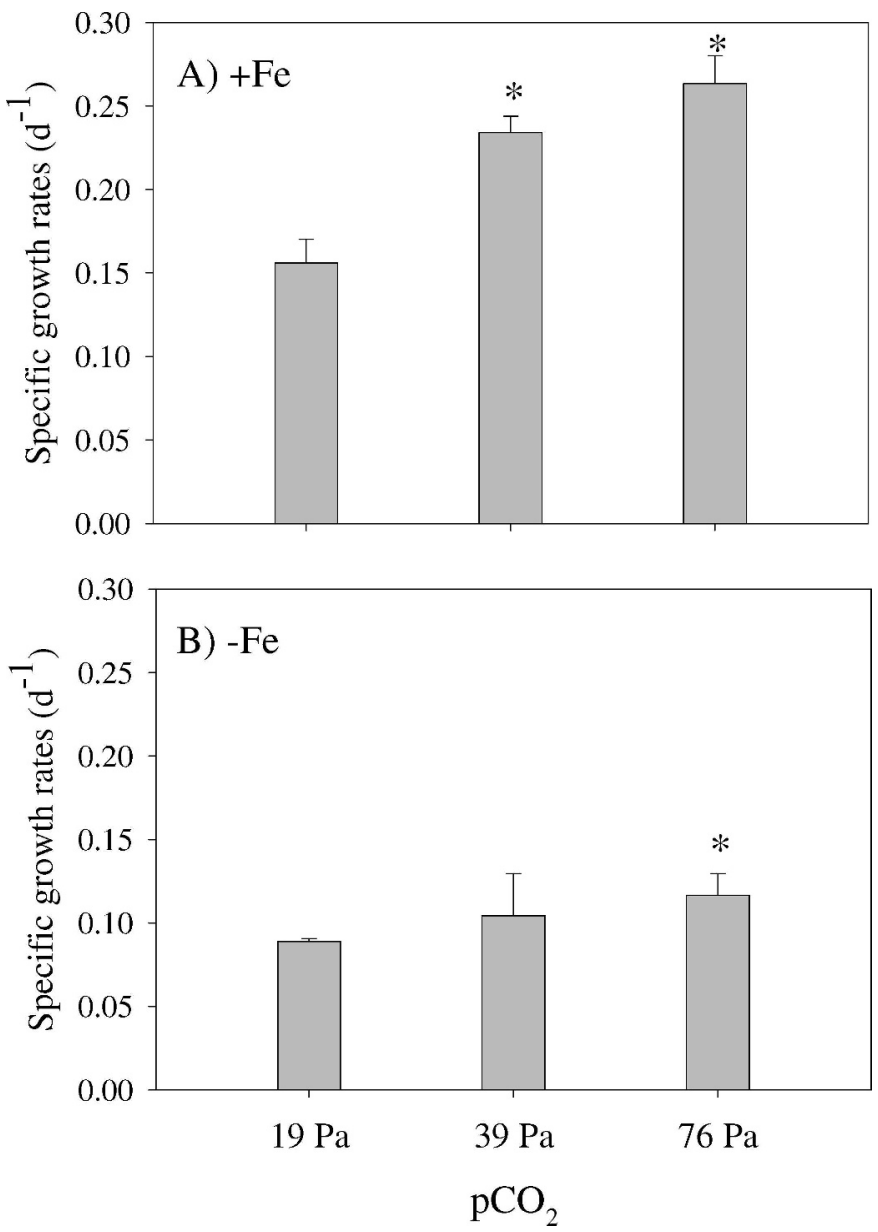

Fig. 1. Cell-specific growth rates of Crocosphaera grown at three different $\mathrm{pCO}_{2}$ levels $(19 \mathrm{~Pa}, 39 \mathrm{~Pa}$, and $76 \mathrm{~Pa})$ under $(\mathrm{A})$ Fe-replete or (B) Fe-limited growth conditions. Values are the means and error bars are the standard deviations of triplicate cultures for each treatment $(n=3)$. Asterisks above histogram bars indicate a treatment average that was significantly different from that of the 19-Pa $\mathrm{pCO}_{2}$ treatment.

$\mathrm{CO}_{2}$ condition, it is noteworthy that under elevated $\mathrm{CO}_{2}$ conditions (76 Pa), the $\mathrm{N}_{2}$ fixation rates of the Fe-limited cultures (Fig. 2B) were only slightly lower than those of the Fe-replete cultures grown at $19-\mathrm{Pa} \mathrm{CO}_{2}$ (Fig. $2 \mathrm{~A}, F_{1,12}=$ $18.3, p=0.05)$.

$\mathrm{C}, \mathrm{Fe}$, and Mo cell quotas and Fe and Mo use efficienciesCellular C quota measurements $(\mathrm{Qc})$ in the experiments indicated that there were differences in cell sizes between treatments (Table 1). Under Fe-replete conditions there were no differences in Qc between the 39- $\mathrm{Pa}$ and $76-\mathrm{Pa}$ treatments, but the cellular $\mathrm{C}$ quotas in the 19-Pa treatment were only $68-73 \%$ of those in the two higher $\mathrm{pCO}_{2}$ levels $\left(F_{1,12}=31.6, p=0.0001 ; F_{1,12}=21, p=0.0006\right)$. Qc values in Fe-limited treatments were only $39-73 \%$ of those in the Fe-replete cultures at the corresponding $\mathrm{pCO}_{2}$ values $\left(F_{1,12}\right.$ $=174, p<0.0001)$, but there were no differences $(p>0.05)$ in $\mathrm{C}$ quotas between the three Fe-limited $\mathrm{pCO}_{2}$ treatments (Table 1). Similar effects of Fe limitation on cell size have been noted in other species of phytoplankton in the past (Sunda and Huntsman 1995; Hutchins et al. 1998).

Our ICPMS results were used to test for a possible relationship between $\mathrm{pCO}_{2}, \mathrm{~N}_{2}$ fixation rates, and cellular quotas of $\mathrm{Fe}$ and $\mathrm{Mo}$, the two trace metal cofactors required for the Crocosphaera nitrogenase enzyme (Tuit et al. 2004). The C-normalized $\mathrm{Fe}$ and Mo quotas ( $\mathrm{Fe}: \mathrm{C}$ and Mo: C ratios) were significantly higher in Fe-replete cultures (Fig. 2C,E) than in Fe-limited ones (Fig. 2D,F), regardless of $\mathrm{CO}_{2}$ condition $\left(F_{1,12}=849, p=0.0005 ; F_{1,12}\right.$ $=49, p=0.0005)$. In Fe-replete cultures, it is also apparent that the C-normalized Fe (Fig. 2C) and Mo (Fig. 2E) quotas increased significantly with increasing $\mathrm{CO}_{2}$ concentrations $\left(F_{1,12}=73, p=0.005\right)$, but this was not the case in Fe-limited cultures (Fig. 2D,F). In general, the overall responses of $\mathrm{Fe}: \mathrm{C}$ ratios (Fig. 2C,D) and $\mathrm{Mo}: \mathrm{C}$ ratios (Fig. 2E,F) to changing $\mathrm{pCO}_{2}$ and $\mathrm{Fe}$ availability were nearly identical to those of $\mathrm{N}_{2}$ fixation rates (Fig. 2A,B).

At an Fe-limited growth rate of $0.1 \mathrm{~d}^{-1}$ under a present day $\mathrm{pCO}_{2}$ of $39 \mathrm{~Pa}$, Crocosphaera had a $\mathrm{Fe}: \mathrm{C}$ ratio of $\sim 27 \mu \mathrm{mol} \mathrm{mol}^{-1}$, and $\mathrm{Fe}: \mathrm{C}$ ratios were very similar in the other two Fe-limited $\mathrm{pCO}_{2}$ treatments (Fig. 2D). Increased $\mathrm{Fe}$ availability at high concentrations (i.e., $450 \mathrm{nmol} \mathrm{L}{ }^{-1}$ ) resulted in an accumulation of intracellular Fe in substantial excess of that required to maintain algal growth rates at $0.1 \mathrm{~d}^{-1}$. For instance, Fe-replete Crocosphaera accumulated $290 \mu \mathrm{mol} \mathrm{Fe} \mathrm{mol}{ }^{-1} \mathrm{C}$ at a growth rate of $\sim 0.27 \mathrm{~d}^{-1}$ in the 76- $\mathrm{Pa} \mathrm{CO}$ treatment (Fig. $2 \mathrm{C}$ ), an 11-fold higher value than the values required to support the Fe-limited growth rates of about $0.1 \mathrm{~d}^{-1}$ observed in all three $\mathrm{Fe}$-limited $\mathrm{pCO}_{2}$ treatments (Fig. 1B).

We estimated the cellular net use efficiencies for $\mathrm{Fe}$ and Mo (IUE and MoUE, respectively) as indices of how efficiently our cultures were able to grow and fix $\mathrm{C}$ as a function of cellular $\mathrm{Fe}$ or $\mathrm{Mo}$ content under our experimental treatments. Net IUE and MoUE values were calculated as the specific growth rates divided by the $\mathrm{Fe}: \mathrm{C}$ or $\mathrm{Mo}: \mathrm{C}$ ratios. In Fe-limited cultures, the net $\mathrm{Fe}$ use efficiencies ranged from 3214 to $3703 \mathrm{~mol} \mathrm{C} \mathrm{mol} \mathrm{Fe} \mathrm{F}^{-1} \mathrm{~d}^{-1}$, with no apparent trend with $\mathrm{pCO}_{2}$ (Table 1). For Fereplete cultures, net IUE values were substantially lower, ranging from 897 to $1300 \mathrm{~mol} \mathrm{C} \mathrm{mol} \mathrm{Fe}{ }^{-1} \mathrm{~d}^{-1}$, and showed a modest but significant inverse trend with $\mathrm{pCO}_{2}$ (Table 1). These Fe-replete net IUE values represent a lower limit estimate, since the cells undoubtedly contained storage $\mathrm{Fe}$ under these growth conditions. For Fe-limited cultures, the net Mo use efficiency ranged from 225,000 to $342,857 \mathrm{~mol}$ $\mathrm{C}$ mol Mo ${ }^{-1} \mathrm{~d}^{-1}$ (Table 1). Contrary to net IUE, effects of $\mathrm{pCO}_{2}$ on net MoUE were not apparent under either Felimited or Fe-replete growth.

$C$ fixation-As with the other rate measurements, most short-term $\mathrm{C}$ fixation parameters from P-E curves were significantly lower in Fe-limited cultures than in Fe-replete cultures, regardless of $\mathrm{CO}_{2}$ conditions (Table 2; $F_{1,12}=$ 1053, $p=0.0005$; Table 2). $\mathrm{CO}_{2}$-driven changes in photosynthetic parameters were also evident $\left(F_{2,12}=186\right.$, $p=0.0005)$, regardless of growth limitation by Fe. Under both $\mathrm{Fe}$ conditions, the two highest $\mathrm{CO}_{2}$ concentration 

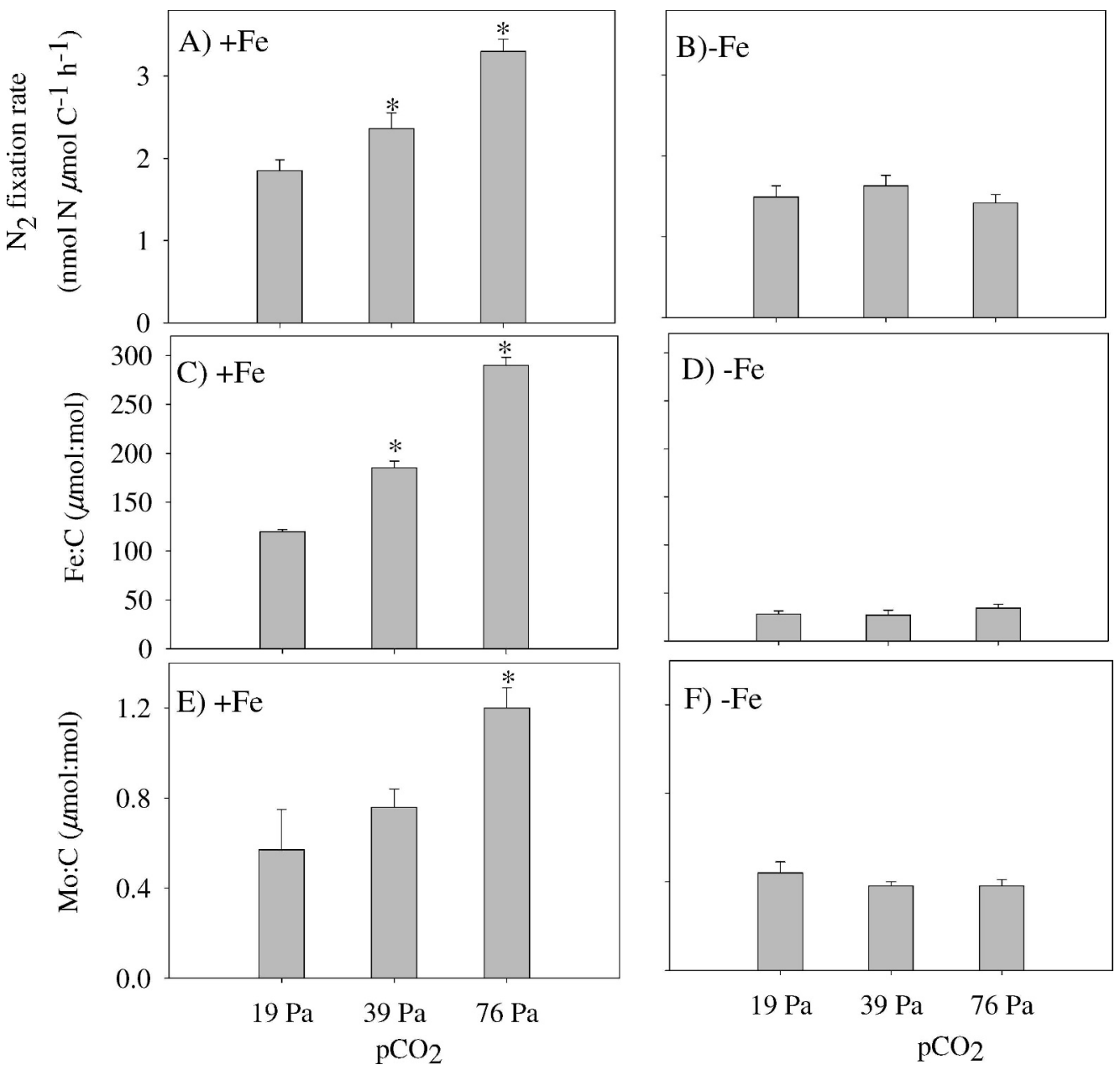

Fig. 2. Crocosphaera cultures were grown at three different $\mathrm{pCO}_{2}$ levels (19 $\mathrm{Pa}, 39 \mathrm{~Pa}$, and $\left.76 \mathrm{~Pa}\right)$ under Fe-replete and Fe-limited growth conditions. Shown are carbon-specific $\mathrm{N}_{2}$ fixation rates of (A) Fe-replete and (B) Fe-limited cultures; Fe: C ratios of (C) Fereplete and (D) Fe-limited cultures; and Mo: C quotas of (E) Fe-replete and (F) Fe-limited cultures. Values are the means and error bars are the standard deviations of triplicate cultures for each treatment, and symbols are as in Fig. 1.

treatments of $76 \mathrm{~Pa}$ and $39 \mathrm{~Pa}$ had $\mathrm{P}_{\mathrm{Bmax}}$ values that were significantly higher than the 19-Pa values in the corresponding Fe treatment $\left(F_{1,12}=309.4, p<0.0001 ; F_{1,12}=\right.$ $69.7, p=0.005 ; F_{1,12}=91.7, p=0.001 ; F_{1,12}=8.4, p=$ $0.01)$. These $\mathrm{pCO}_{2}$-mediated increases were $64 \%(76 \mathrm{~Pa})$ and $30 \%(39 \mathrm{~Pa}$ ) in Fe-replete cultures and $76 \%$ and $24 \%$ in Fe-limited cultures, respectively.
Treatment-related trends in the slope of the light-limited portion of the P-E curve, $\alpha$, were in general similar to those for $\mathrm{P}_{\mathrm{Bmax}}$ (Table 2). In Fe-replete cultures, the values of $\alpha$ increased with increasing $\mathrm{CO}_{2}$ concentrations. In comparison, the values of $\alpha$ varied slightly and showed no significant differences between $19 \mathrm{~Pa}$ and $39 \mathrm{~Pa} \mathrm{CO}_{2}$ in Fe-limited cultures $\left(F_{1,12}=1.5, p=0.40\right)$, but they had

Table 1. Net iron (Fe) use efficiency (IUE, mol carbon [C] $\mathrm{mol} \mathrm{Fe}^{-1} \mathrm{~d}^{-1}$ ); net molybdenum (Mo) use efficiency (MoUE, mol C mol $\left.\mathrm{Mo}^{-1} \mathrm{~d}^{-1}\right)$; $\mathrm{C}$ : nitrogen $(\mathrm{N}), \mathrm{N}$ : phosphorus $(\mathrm{P})$, and $\mathrm{C}: \mathrm{P}$ ratios (mol: mol); chlorophyll $a(\mathrm{Chl} a)$ to $\mathrm{C}$ ratios $(\mu \mathrm{mol}: \mathrm{mol})$; and cellular $\mathrm{C}$ quota or content $\left(\mathrm{Qc}\right.$, fmol $\mathrm{C}$ cell $\left.{ }^{-1}\right)$ of Crocosphaera during steady-state Fe-replete and Fe-limited growth in three different partial pressure of $\mathrm{CO}_{2}\left(\mathrm{pCO}_{2}\right)$ treatments. Values given are the means and values in parentheses are the standard deviations of measurements on triplicate cultures.

\begin{tabular}{ccccccccc}
\hline \hline Treatments & $\mathrm{pCO}_{2}(\mathrm{~Pa})$ & $\mathrm{IUE}$ & $\mathrm{MoUE}$ & $\mathrm{C}: \mathrm{N}$ & $\mathrm{N}: \mathrm{P}$ & $\mathrm{C}: \mathrm{P}$ & $\mathrm{Chl} a: \mathrm{C}$ & $\mathrm{Qc}$ \\
\hline$+\mathrm{Fe}$ & 76 & 897 & 216,667 & $7.3(0.2)$ & $19.2(0.4)$ & $140(5)$ & $73(2)$ & $0.26(0.03)$ \\
& 39 & 1243 & 302,632 & $6.9(0.2)$ & $18.8(0.4)$ & $130(2)$ & $83(12)$ & $0.28(0.02)$ \\
$-\mathrm{Fe}$ & 19 & 1333 & 280,702 & $7.4(0.2)$ & $15.6(0.8)$ & $116(4)$ & $67(10)$ & $0.19(0.02)$ \\
& 76 & 3529 & 342,857 & $6.5(0.1)$ & $16.2(0.9)$ & $104(6)$ & $51(10)$ & $0.12(0.005)$ \\
& 39 & 3703 & 285,714 & $6.3(0.0)$ & $16.1(0.2)$ & $101(1)$ & $44(2)$ & $0.11(0.004)$ \\
& 19 & 3214 & 225,000 & $6.4(0.2)$ & $15.8(0.5)$ & $101(6)$ & $44(13)$ & $0.14(0.01)$ \\
\hline
\end{tabular}


Table 2. Functional photosynthetic performance parameters for Crocosphaera during steady-state iron $(\mathrm{Fe})$-replete and $\mathrm{Fe}$ limited growth in three different partial pressure of $\mathrm{CO}_{2}\left(\mathrm{pCO}_{2}\right)$ treatments. Shown are maximum cell-specific carbon $(\mathrm{C})$ fixation rate $\left(\mathrm{P}_{\mathrm{Bmax}}\right.$, ng $\mathrm{C}$ cell $\left.{ }^{-1} \mathrm{~h}^{-1}\right), \alpha\left[\mathrm{ng} \mathrm{C} \mathrm{h} \mathrm{h}^{-1} \text { (cell) }\right)^{-1}$ ( $\mu$ mol photon $\left.\mathrm{m}^{-2} \mathrm{~s}^{-1}\right)^{-1}$, and the light saturation point and index of light adaptation $\left(E_{k}, \mu\right.$ mol photon $\left.\mathrm{m}^{-2} \mathrm{~s}^{-1}\right)$. Values given are the means and values in parentheses are the standard deviations of measurements on triplicate cultures.

\begin{tabular}{ccclc}
\hline \hline Treatments & $\mathrm{pCO}_{2}(\mathrm{~Pa})$ & $\mathrm{P}_{\mathrm{Bmax}}$ & \multicolumn{1}{c}{$\alpha$} & $\mathrm{E}_{\mathrm{k}}$ \\
\hline$+\mathrm{Fe}$ & 76 & $133(5)$ & $0.70(0.015)$ & $190(8)$ \\
& 39 & $106(3)$ & $0.56(0.04)$ & $190(10)$ \\
$-\mathrm{Fe}$ & 19 & $81(5)$ & $0.27(0.03)$ & $300(20)$ \\
& 76 & $67(3)$ & $0.55(0.08)$ & $122(27)$ \\
& 39 & $47(02)$ & $0.32(0.04)$ & $147(19)$ \\
& 19 & $38(1)$ & $0.23(0.02)$ & $165(28)$ \\
\hline
\end{tabular}

significant increases from $39 \mathrm{~Pa}$ to $76 \mathrm{~Pa} \mathrm{CO}_{2} . \alpha$ values in $\mathrm{Fe}$-replete cultures were significantly greater relative to $\mathrm{Fe}$ limited cultures at all $\mathrm{CO}_{2}$ concentrations $\left(F_{1,12}=25, p=\right.$ 0.0008), except for the lowest $\mathrm{pCO}_{2}$ at $19 \mathrm{~Pa}$, which had very similar $\alpha$ values under both Fe conditions $\left(F_{1,12}=1.7\right.$, $p=0.37$.

The light saturation constant $E_{k}$ was evaluated from the ratios of $\mathrm{P}_{\mathrm{Bmax}}$ to $\alpha$ (Table 2). As a result of greater increases in $\mathrm{P}_{\mathrm{Bmax}}$ than in $\alpha$ for Fe-replete cultures, the ratios of $\mathrm{P}_{\mathrm{Bmax}}$ to $\alpha$ increased modestly relative to values in the Fe-limited cultures $\left(F_{1,12}=63, p=0.0005\right)$. In Felimited cultures the values of both $\mathrm{P}_{\mathrm{Bmax}}$ and $\alpha$ were enhanced with increasing $\mathrm{CO}_{2}$ concentrations, and, hence, resulted in no evident $\mathrm{CO}_{2}$ effects on $\mathrm{E}_{\mathrm{k}}\left(F_{2,6}=2.7, p=\right.$ 0.5). However, in Fe-replete cultures, the greater relative decreases in $\alpha$ than in $\mathrm{P}_{\mathrm{Bmax}}$ under the 19-Pa treatment resulted in significant increases in $\mathrm{E}_{\mathrm{k}}$ relative to the invariant values in the other two $\mathrm{CO}_{2}$ concentrations $\left(F_{2,6}\right.$ $=52.4, p=0.0005 ; F=22, p=0.003$ ).

The $\mathrm{pCO}_{2}$-mediated trends for daily primary production in Crocosphaera were in general similar to those observed for $\mathrm{N}_{2}$ fixation (Fig. 3). Like the trends in $\mathrm{P}_{\mathrm{Bmax}}$ obtained from short-term P-E curves (Table 2), increases in $\mathrm{CO}_{2}$ in Fe-replete cultures stimulated 24-h primary production rates under the experimental culture light conditions (Fig. 3A). Primary production rates in the Fe-replete 76$\mathrm{Pa}$ treatment were twofold higher than in the Fe-replete 19$\mathrm{Pa}$ treatment. For Fe-limited cultures grown at a $\mathrm{pCO}_{2}$ of $76 \mathrm{~Pa}$, primary productivity was elevated by $150-230 \%$ compared with the other two $\mathrm{pCO}_{2}$ treatments (Fig. 3B). Paired comparisons of Fe-replete and Fe-limited cultures at the same $\mathrm{pCO}_{2}$ concentration showed significantly elevated primary production at each $\mathrm{pCO}_{2}$ with increasing $\mathrm{Fe}$ availability. To some extent the effects of increasing $\mathrm{CO}_{2}$ and decreasing $\mathrm{Fe}$ offset each other; for instance, there was no significant difference in primary production rates between the Fe-replete 19-Pa (Fig. 3A) and the Fe-limited 76-Pa treatments (Fig. 3B; $F_{1,12}=3.0, p=0.17$ ).

Photosynthetic pigments - In general, the C normalized content of photosynthetic pigments was affected much more by $\mathrm{Fe}$ than by $\mathrm{CO}_{2}$. Fe-replete Crocosphaera cells

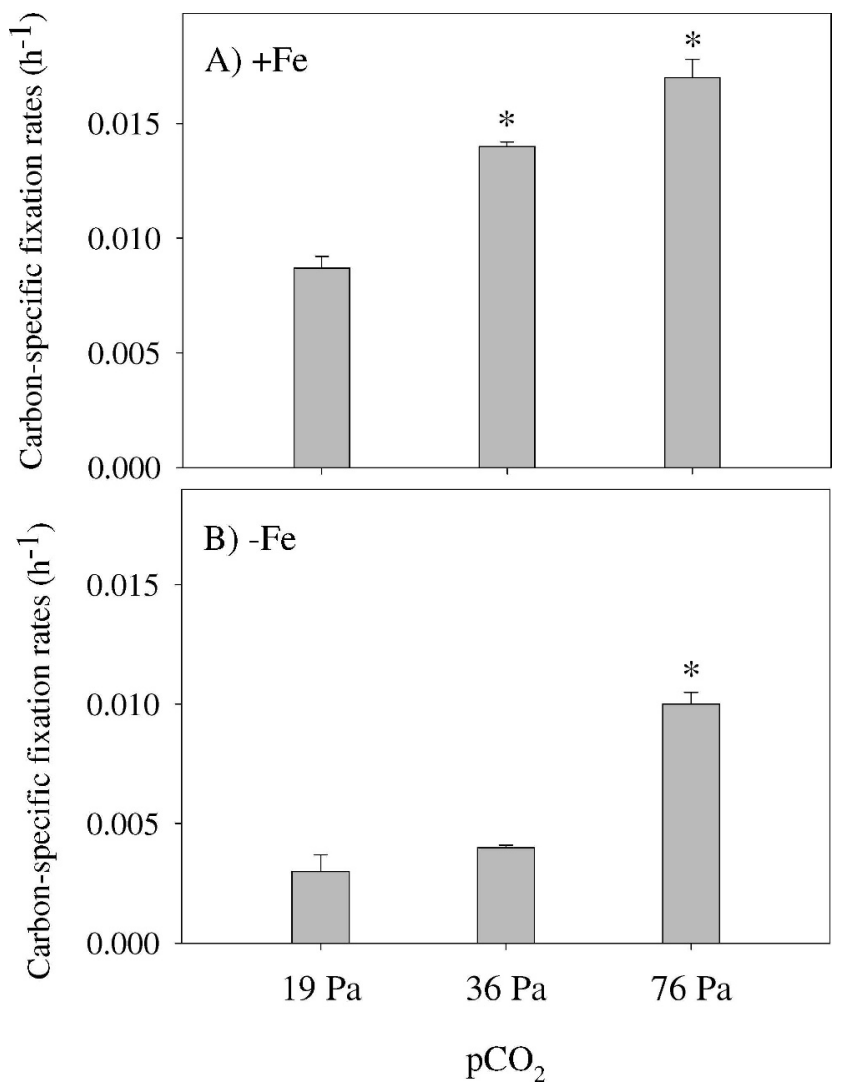

Fig. 3. Carbon-specific $\mathrm{CO}_{2}$ fixation rates of Crocosphaera grown at three different $\mathrm{pCO}_{2}$ levels $(19 \mathrm{~Pa}, 39 \mathrm{~Pa}$, and $76 \mathrm{~Pa}$ ) under (A) Fe-replete or (B) Fe-limited growth conditions. Values are the means and error bars are the standard deviations of triplicate cultures for each treatment, and symbols are as in Fig. 1.

grown under two elevated- $\mathrm{pCO}_{2}$ conditions show somewhat higher PE content than do cells grown at a $\mathrm{pCO}_{2}$ of $19 \mathrm{~Pa}\left(F_{1,12}=8.3, p=0.02\right)$, but there was no significant difference between these two elevated- $\mathrm{pCO}_{2}$ conditions (Fig. 4A; $F_{1,12}=0.1, p=0.92$ ). For PC, Fe-replete cells grown at a $\mathrm{pCO}_{2}$ of $76 \mathrm{~Pa}$ had a significantly higher pigment content than those grown at $19 \mathrm{~Pa}\left(F_{1,12}=6.4, p\right.$ $=0.03)$, but PC content was not significantly different between $19 \mathrm{~Pa}$ and $39 \mathrm{~Pa}$ or between $39 \mathrm{~Pa}$ and $76 \mathrm{~Pa}\left(F_{1,12}\right.$ $=3.4, p=0.1 ; F_{1,12}=1.6, p=0.2$ ). Elevated $\mathrm{CO}_{2}$ did not change the much lower and invariant cellular phycobilin pigment content of Fe-limited cultures (Fig. 4C). A comparison of $\mathrm{C}$ normalized $\mathrm{Chl} a$ cells in Fe-replete cultures (Fig. 4B) with the Fe-limited cultures (Fig. 4D) showed a decrease in the cell-normalized amount of this pigment. In contrast, in both Fe-replete and Fe-limited cultures, Chl $a$ contents were relatively unchanged between $\mathrm{pCO}_{2}$ treatments (Fig. 4B,D).

Elemental ratios - $\mathrm{Fe}$ availability had a minor effect on the ratios of $\mathrm{C}$ to $\mathrm{N}$, regardless of $\mathrm{pCO}_{2}$ concentrations (Table 1). In general, the molar ratios of $\mathrm{C}$ to $\mathrm{N}$ for the cells grown under Fe-replete conditions were slightly but significantly higher than the values from Fe-limited cultures, varying from 6.4 to 7.4. However, for both Fe- 

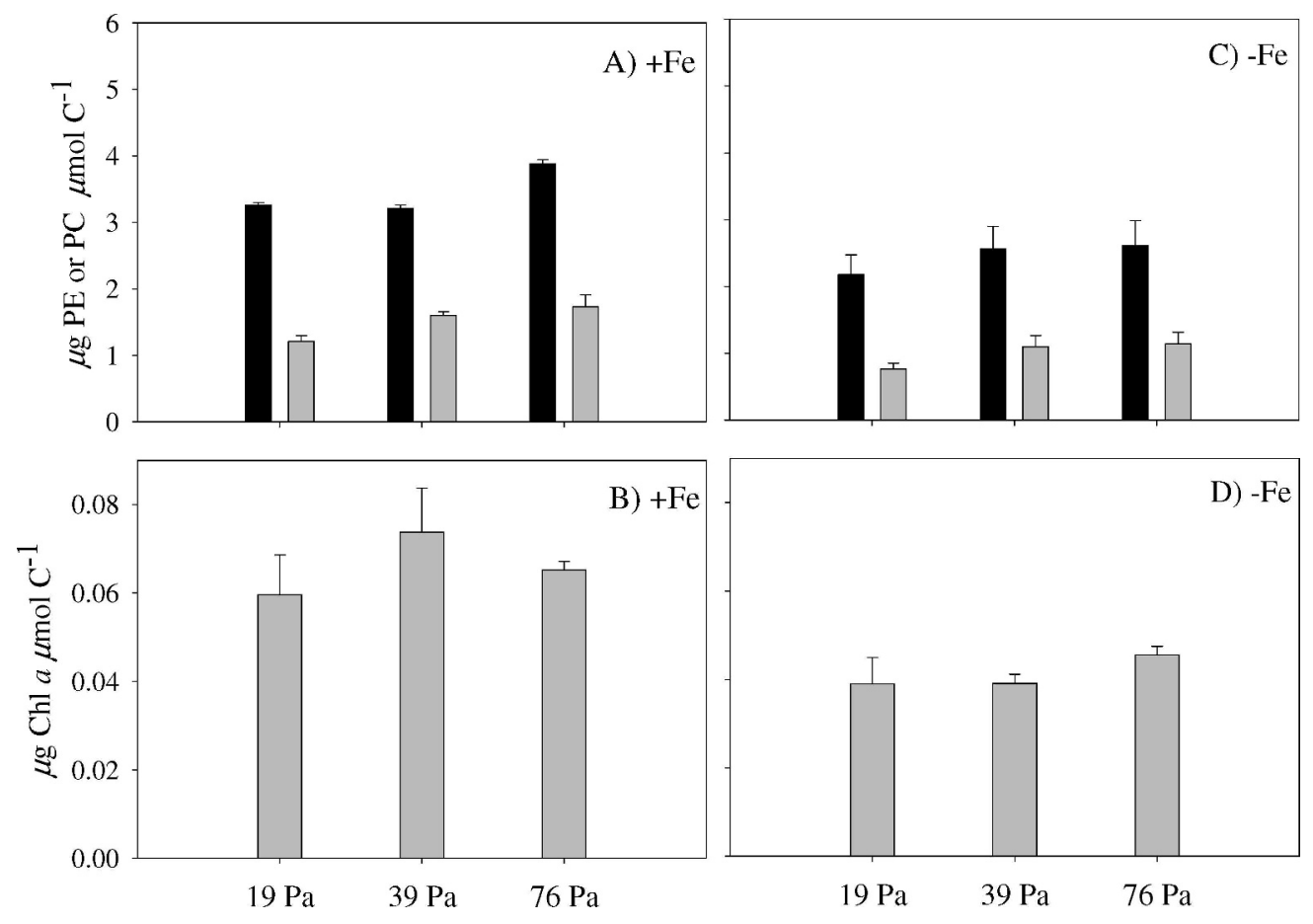

Fig. 4. Photosynthetic pigments $(\mu \mathrm{g} \mathrm{C}-1)$ of Crocosphaera grown at three different $\mathrm{pCO}_{2}$ levels $(19 \mathrm{~Pa}, 39 \mathrm{~Pa}$, and $76 \mathrm{~Pa}) \mathrm{under}$ Fereplete or Fe-limited growth conditions. Phycoerythrin (gray bars) and phycocyanin (black bars) in (A) Fe-replete and (C) Fe-limited cultures and Chl $a$ in (B) Fe-replete and (D) Fe-limited cultures. Values given are the means and error bars are the standard deviations of measurements on triplicate cultures.

replete and Fe-limited cultures, the cellular $\mathrm{C}: \mathrm{N}$ ratios were relatively invariant among the three $\mathrm{pCO}_{2}$ treatments.

Molar N : P ratios of Crocosphaera cells ranged from 14 to 17 for all the treatments, and there was no Fe effect (Table 1). Only in Fe-replete cultures did N:P ratios increase by $21 \%$ at $39 \mathrm{~Pa}$ and $76 \mathrm{~Pa} \mathrm{pCO}_{2}$, as compared to $19 \mathrm{~Pa}$, but there was no significant difference between the two higher $\mathrm{pCO}_{2}$ treatments (Table 1; $F_{1,12}=0.52, p=$ $0.48)$. The $\mathrm{N}: \mathrm{P}$ ratio remained unchanged in Fe-limited cultures across the $\mathrm{CO}_{2}$ gradient.

In Fe-replete cultures the molar $\mathrm{C}: \mathrm{P}$ ratios increased with increasing $\mathrm{pCO}_{2}$ concentrations; however, in $\mathrm{Fe}$ limited cultures, the cellular $\mathrm{C}: \mathrm{P}$ ratios were not significantly different from each other in the three $\mathrm{CO}_{2}$ concentrations (Table $1 ; F_{2,12}=0.35, p=0.72$ ). The cellular $\mathrm{C}: \mathrm{P}$ ratios for both the 76-Pa and 39-Pa treatments were significantly higher in Fe-replete grown cultures relative to Fe-limited ones (Table 1; $F_{1,12}=186, p=$ 0.0005). The differences in $\mathrm{C}: \mathrm{P}$ ratios between $\mathrm{Fe}$ treatments were, however, relatively minor under the 19$\mathrm{Pa} \mathrm{CO} 2$ conditions $\left(F_{1,12}=16.6, p=0.02\right.$; Table 1$)$.

\section{Discussion}

Biogeochemical implications - Recently, several studies examining the marine diazotrophic cyanobacterium Trichodesmium have shown significant increases in $\mathrm{N}_{2}$ fixation and photosynthesis in response to elevated $\mathrm{CO}_{2}$ concentration (Hutchins et al. 2007; Levitan et al. 2007; Ramos et al. 2007). Our data extend these findings to encompass the marine unicellular $\mathrm{N}_{2}$-fixing cyanobacterium Crocosphaera.
This group is now recognized as being perhaps equally as important as Trichodesmium to the ocean $\mathrm{N}$ cycle (Montoya et al. 2004).

As with Trichodesmium, there is a strong positive correlation between $\mathrm{pCO}_{2}$ levels and $\mathrm{N}_{2}$ fixation rates in Crocosphaera grown under Fe-replete conditions. In contrast, $\mathrm{N}_{2}$ fixation in Fe-limited Crocosphaera cultures was not responsive to changing $\mathrm{pCO}_{2}$ levels. Thus, the relationship between $\mathrm{pCO}_{2}, \mathrm{~N}_{2}$ fixation, and Fe limitation in Crocosphaera differs in a fundamental way from the interactions between $\mathrm{pCO}_{2}$ and $\mathrm{N}_{2}$ fixation and $\mathrm{P}$ limitation in Trichodesmium. Hutchins et al. (2007) showed that P-limited Trichodesmium at present day $\mathrm{pCO}_{2}$ rates should really be considered to be co-limited by both $\mathrm{P}$ and $\mathrm{C}$, since growth and $\mathrm{N}$ and $\mathrm{C}$ fixation rates will increase in response to either phosphate or $\mathrm{CO}_{2}$ additions. $\mathrm{Fe}$ limitation in Crocosphaera, however, negates the effects of changing $\mathrm{pCO}_{2}$ on $\mathrm{N}_{2}$ fixation, indicating that future $\mathrm{CO}_{2}$-mediated increases in unicellular diazotrophy may ultimately be governed by $\mathrm{Fe}$ availability.

In fact, the results of our study demonstrate that the tight coupling between $\mathrm{pCO}_{2}$ and $\mathrm{N}_{2}$ fixation rates in Crocosphaera also implies a similar, albeit indirect, coupling between $\mathrm{pCO}_{2}$ and cellular $\mathrm{Fe}$ requirements. This interaction can be illustrated by re-plotting the data shown in Fig. 2. Over the three $\mathrm{CO}_{2}$ concentrations we examined, the cellular Fe quota of Fe-replete Crocosphaera is linearly related to $\mathrm{N}_{2}$ fixation rates (Fig. 5A). Because $\mathrm{N}_{2}$ fixation is in turn a linear function of $\mathrm{pCO}_{2}$ (Fig. 5B), Fe quotas are therefore also a linear function of $\mathrm{CO}_{2}$ concentration. A similar relationship applies to cell quotas of the other 

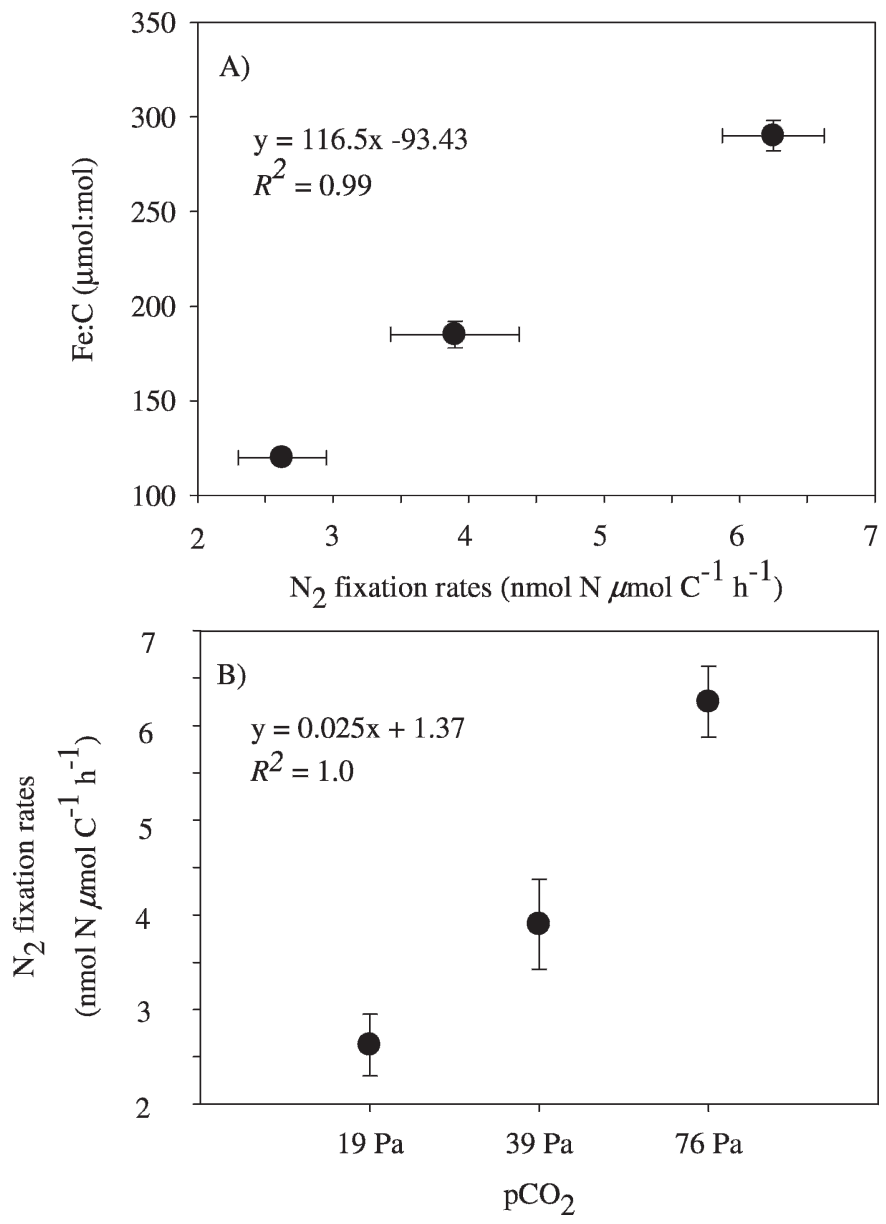

Fig. 5. (A) $\mathrm{Fe}: \mathrm{C}$ ratios vs. $\mathrm{N}_{2}$ fixation rates and (B) $\mathrm{N}_{2}$ fixation rates vs. $\mathrm{pCO}_{2}$ for Fe-replete Crocosphaera grown at three different $\mathrm{pCO}_{2}$ levels $(19 \mathrm{~Pa}, 39 \mathrm{~Pa}$, and $76 \mathrm{~Pa})$. Values given are the means and error bars are the standard deviations of measurements on triplicate cultures.

element involved as a co-factor in $\mathrm{N}_{2}$ fixation, Mo (data not shown).

Thus, it appears likely that future rising $\mathrm{pCO}_{2}$ will have a major effect on not only the biogeochemical cycle of $\mathrm{N}$ (by stimulating $\mathrm{N}_{2}$ fixation) but also secondarily on the biogeochemistry of $\mathrm{Fe}$ (and $\mathrm{Mo}$ ). If $\mathrm{N}_{2}$ fixation by Crocosphaera increases as a result of " $\mathrm{CO}_{2}$ fertilization" of the ocean over the coming century, the consequent elevated cellular $\mathrm{Fe}$ requirements necessary to support these higher $\mathrm{N}_{2}$ fixation rates may also simultaneously drive this cyanobacterium toward $\mathrm{Fe}$ limitation.

Paleo-climate regulation implications-Hutchins et al. (2007) found that as a result of severe C limitation, Trichodesmium are unable to survive in long-term acclimated growth at a low $\mathrm{pCO}_{2}$ of $15 \mathrm{~Pa}$. They suggested that under glacial era low- $\mathrm{pCO}_{2}$ atmospheric conditions, this constraint could result in down-regulation of new $\mathrm{N}$ inputs to the ocean from $\mathrm{N}_{2}$ fixation and, thus, could potentially lead to lower oceanic inventories of fixed N. Ultimately this down-regulation could result in a weakened biological pump, reduced oceanic $\mathrm{CO}_{2}$ uptake, and stabilization of or even an increase in atmospheric $\mathrm{pCO}_{2}$. Our results demonstrating $\mathrm{C}$ limitation of $\mathrm{N}_{2}$ fixation by Crocosphaera grown at glacial $\mathrm{pCO}_{2}$ levels of $19 \mathrm{~Pa}$ support and strengthen this negative feedback scenario. In fact, the observed decrease in $\mathrm{N}_{2}$ fixation and growth rates that we observed from $39 \mathrm{~Pa}$ to $19 \mathrm{~Pa}$ was much larger than the decrease we observed from $76 \mathrm{~Pa}$ to $39 \mathrm{~Pa}$, indicating that the magnitude of glacial era to present day differences could be much larger than the magnitude of present day to year 2100 differences. It may not be coincidental that the limiting $\mathrm{pCO}_{2}$ levels that virtually shut down $\mathrm{N}_{2}$ fixation by both Trichodesmium and Crocosphaera are quite close to the minimum atmospheric values at the last glacial maximum ( $\sim 19 \mathrm{~Pa}$; Petit et al. 1999). Future investigations will be needed to examine this potential atmosphere and ocean biology feedback loop in more detail and to determine the possible consequences for long-term climate regulation processes.

Growth, $\mathrm{N}_{2}$ fixation, and $C$ fixation under variable $\mathrm{pCO}_{2}$ and $\mathrm{Fe}-\mathrm{N}_{2}$ fixation by cyanobacteria is dependent on supplies of reductant, adenosine triphosphate (ATP), and $\mathrm{C}$-derived metabolites. Hence, it is not surprising that under Fe-replete and Fe-elevated $\mathrm{pCO}_{2}$ conditions, increases in both light-limited and light-saturated photosynthetic rates produced a larger pool of $\mathrm{C}$ and energy to support $\mathrm{N}_{2}$ fixation and growth. This is consistent with the increased slope of the light-limited photosynthetic rate $\alpha$ with elevated $\mathrm{pCO}_{2}$ and $\mathrm{Fe}$ repletion, indicating that the cells grown under these conditions would possess a higher capacity to assimilate $\mathrm{C}$. By contrast, in Fe-limited cultures $\mathrm{N}_{2}$ fixation was unchanged across a range of $\mathrm{pCO}_{2}$, despite similar increases in parameters such as $\mathrm{P}_{\mathrm{Bmax}}$ and $\alpha$, which is inconsistent with this model of $\mathrm{N}_{2}$ fixation stimulation driven mainly by enhanced $\mathrm{C}$ fixation rates. The cultures grown under Fe-limited conditions showed much smaller increases in growth rates with increasing $\mathrm{pCO}_{2}$ concentrations compared to cultures grown under Fe-replete conditions, indicating that the cells were largely unable to compensate for the low availability of $\mathrm{Fe}$ despite greater external $\mathrm{CO}_{2}$ availability.

Crocosphaera segregates $\mathrm{N}_{2}$ fixation from photosynthesis by fixing $\mathrm{N}_{2}$ only at night, a fundamentally different strategy from that of Trichodesmium, which fixes $\mathrm{N}_{2}$ and $\mathrm{CO}_{2}$ simultaneously during the day. Thus, in Crocosphaera energy and reductant to fuel energetically expensive $\mathrm{N}_{2}$ fixation comes from respiratory pathways using stored photosynthate. Competition between $\mathrm{N}_{2}$ and $\mathrm{CO}_{2}$ fixation pathways for photosynthetically derived energy and reductant has been suggested as a possible reason for enhancement of both processes under high- $\mathrm{CO}_{2}$ conditions in Trichodesmium (Hutchins et al. 2007). This type of competition may also occur in Crocosphaera, despite the temporal decoupling of $\mathrm{C}$ fixation and $\mathrm{N}_{2}$ fixation in this genus.

As long as ample $\mathrm{Fe}$ supplies are available for both processes, increased $\mathrm{C}$ fixation due to elevated $\mathrm{CO}_{2}$ should also result in the simultaneous stimulation of $\mathrm{N}_{2}$ fixation in order to maintain balanced cellular $\mathrm{C}: \mathrm{N}$ ratios. Fe limitation in particular affects the photosynthetic appara- 
tus and electron transport (Raven et al. 1999), resulting in decreased photosynthesis for Fe-limited $\mathrm{N}_{2}$-fixers ( $\mathrm{Fu}$ and Bell 2003). The major electron carriers requiring Fe, such as cytochromes and $\mathrm{Fe}-\mathrm{S}$ proteins, are all involved in both photosynthesis and respiration. Thus, Fe limitation impinges upon a wide range of relevant cellular processes, from synthesis of nitrogenase to supplies of photosynthetically generated ATP and/or reducing equivalents to support $\mathrm{C}$ fixation, $\mathrm{N}_{2}$ fixation, and DIC transport.

Pigments under variable $\mathrm{pCO}_{2}$ and $\mathrm{Fe}$-Reductions in cellular pigments are commonly observed in Fe-limited phytoplankton cells. Reductions in cellular $\mathrm{Chl} a$ and accessory pigments $\mathrm{PC}$ and $\mathrm{PE}$ also indicated that $\mathrm{Fe}$ availability affected the production of photosynthetic pigments by Crocosphaera in our study. However, our study showed that $\mathrm{Chl} a$-normalized light-saturated photosynthesis was also affected by $\mathrm{Fe}$ availability, contrary to the results of a study of Trick et al. (1995) using the cyanobacterium Oscillatoria. This indicates that light-saturated photosynthesis is not limited by Chl $a$ content in Crocosphaera and confirms the results of the study of Sandmann (1985), in which the Chl $a$ of Fe-limited Aphanocapsa was in excess, was associated nonfunctionally, or was less efficiently utilized.

Regardless of $\mathrm{Fe}$ condition, cellular $\mathrm{Chl} a$ content remained unchanged under different $\mathrm{pCO}_{2}$ concentrations. This result is contrary to those of a study of the nondiazotrophic unicellular marine cyanobacterium Synechococcus, in which cellular $\mathrm{Chl} a$ content increased with increasing $\mathrm{pCO}_{2}$ levels ( $\mathrm{Fu}$ et al. 2007). However, invariant cellular Chl $a$ in response to changing availability of DIC or $\mathrm{pCO}_{2}$ has been reported in other cyanobacteria, such as Anacytis nidulans, as well as in some eukaryotic algae, such as Scenedesmus obtusius, Dunaliella viridis, and the raphidiphyte Heterosigma (Gordillo et al. 2003; Müller et al. 1993; Fu et al. 2008). Gordillo et al. (2003) suggested that this could be because qualitative rather than quantitative changes in the light harvesting machinery are involved in reaching higher photosynthetic rates under $\mathrm{CO}_{2}$ enrichment.

Crocosphaera cellular $\mathrm{PC}$ and $\mathrm{PE}$ pigments in the $75-\mathrm{Pa}$ treatment were slightly higher than in the 19-Pa treatment under Fe-replete conditions. No effect of $\mathrm{CO}_{2}$ was observed on phycobilin content in Crocosphaera under Fe-limited conditions. $\mathrm{PC}$ is the main component of phycobiliproteins in Crocosphaera, and the ratio of PC to Chl $a$ was significantly higher in Fe-replete cultures compared to Felimited ones. This is in agreement with the study of Trick et al. (1995), since in our experiment the ratio significantly increased under elevated $\mathrm{pCO}_{2}$ in Fe-replete cultures but not in Fe-limited ones. Hence, $\mathrm{Fe}$ availability by itself has an effect on the ratio. In general, it appears that the photosynthetic apparatus of Crocosphaera is more affected by changes in $\mathrm{Fe}$ availability than by changes in $\mathrm{CO}_{2}$ availability.

Implications for interactions between the $C, N, P$, and $\mathrm{Fe}$ cycles - There is relatively little information on how the availability of $\mathrm{Fe}$ affects the elemental ratios of marine diazotrophs, especially marine unicellular $\mathrm{N}_{2}$-fixers such as Crocosphaera. Studies using Trichodesmium IMS101 and the unicellular $\mathrm{N}_{2}$-fixer Cyanothece (Berman-Frank et al. 2001, 2007) showed that $\mathrm{Fe}$ availability has little effect on the $\mathrm{C}: \mathrm{N}: \mathrm{P}$ elemental ratios. Our Crocosphaera results showed that increased $\mathrm{Fe}$ availability increased $\mathrm{C}: \mathrm{N}$ and $\mathrm{C}: \mathrm{P}$ ratios, but $\mathrm{N}: \mathrm{P}$ ratios remained stable. Also, it is noteworthy that in general, the $\mathrm{C}: \mathrm{P}$ and $\mathrm{N}: \mathrm{P}$ ratios of Crocosphaera are higher than the ratios of Trichodesmium from the study of Berman-Frank et al. (2001), particularly in Fe-limited cultures. Assuming that differences between the growth conditions of the two studies were not significant, our data indicate that Crocosphaera require less $\mathrm{P}$ and $\mathrm{N}$ relative to $\mathrm{C}$ to maintain growth under $\mathrm{Fe}-$ limited conditions.

Levitan et al. (2007) reported changes in Trichodesmium $\mathrm{C}: \mathrm{N}$ ratios from enhanced $\mathrm{pCO}_{2}$, but these changes were not observed by Hutchins et al. (2007). Regardless of Fe conditions, the $\mathrm{C}: \mathrm{N}$ ratios of Crocosphaera were not affected by changing $\mathrm{CO}_{2}$ concentration. As suggested by Hutchins et al. (2007) for Trichodesmium, it appears that simultaneous stimulation of both $\mathrm{N}_{2}$ fixation and $\mathrm{C}$ fixation by rising $\mathrm{CO}_{2}$ allows Crocosphaera to maintain a balanced C:N ratio. Since both diazotrophs ultimately transfer much of their fixed $\mathrm{C}$ and $\mathrm{N}$ to the rest of the plankton community (Mulholland 2007), this indicates that overall biological $\mathrm{C}: \mathrm{N}$ stoichiometry could remain relatively stable despite changes in past and future atmospheric $\mathrm{pCO}_{2}$.

$\mathrm{CO}_{2}$ enrichment did not affect the ratios of $\mathrm{C}$ to $\mathrm{P}$ or of $\mathrm{N}$ to $\mathrm{P}$ for Crocosphaera cultures grown under Fe-limited conditions. Crocosphaera grown under Fe-replete conditions did, however, show similar trends to Trichodesmium (Hutchins et al. 2007), in that $\mathrm{C}: \mathrm{P}$ and $\mathrm{N}: \mathrm{P}$ ratios increased with increasing $\mathrm{pCO}_{2}$. In general, though, $\mathrm{pCO}_{2}$-driven changes in Crocosphaera $\mathrm{C}: \mathrm{P}$ and $\mathrm{N}: \mathrm{P}$ ratios were smaller than those observed for Trichodesmium.

These higher $\mathrm{C}: \mathrm{P}$ and $\mathrm{N}: \mathrm{P}$ ratios at enhanced $\mathrm{CO}_{2}$ levels in both Crocosphaera and Trichodesmium are consistent with the suggestion of Hutchins et al. (2007) that unlike $\mathrm{N}_{2}$ and $\mathrm{CO}_{2}$ fixation, phosphate uptake by marine $\mathrm{N}_{2}$-fixers is not regulated by changing $\mathrm{pCO}_{2}$. The possible biogeochemical consequences of enhanced $\mathrm{N}$ and $\mathrm{C}$ incorporation without a comparable increase in $\mathrm{P}$ incorporation could include $\mathrm{P}$ limitation of both the diazotrophs themselves as well as an increased likelihood of $\mathrm{P}$ limitation in the rest of the phytoplankton community, since supplies of new fixed $\mathrm{N}$ will be enhanced relative to $\mathrm{P}$ supply. Higher $\mathrm{C}: \mathrm{P}$ ratios with rising $\mathrm{CO}_{2}$ are also biogeochemically significant, since they could increase $\mathrm{C}$ storage by the ocean's biological pump relative to $\mathrm{P}$ utilization by the biota.

The effects of $\mathrm{CO}_{2}$ on elemental ratios in phytoplankton are species-specific. $\mathrm{C}: \mathrm{N}: \mathrm{P}$ ratios in the cyanobacterium Prochlorococcus grown under nutrient-replete conditions do not vary with $\mathrm{pCO}_{2}$ changes; however, the ratios of $\mathrm{C}$ to $\mathrm{P}$ and $\mathrm{N}$ to $\mathrm{P}$ of Synechococcus are considerably higher at increased $\mathrm{pCO}_{2}$ (Fu et al. 2007). It has been suggested that groups like Synechoccoccus that are able to take up $\mathrm{CO}_{2}$ actively are likely to show much larger cellular stoichiom- 
etry changes with varying $\mathrm{pCO}_{2}$ than are those (like Prochlorococcus) that are thought to rely largely on $\mathrm{HCO}_{3}^{-}$uptake (Burkhardt et al. 1999; Fu et al. 2007). This line of reasoning is based on the fact that the concentration of $\mathrm{HCO}_{3}^{-}$changes only marginally with doubled $\mathrm{pCO}_{2}$. However, many cyanobacteria are known to possess a wide variety of CCMs (Badger et al. 2006), so predictions based on changing external DIC species alone could be misleading. To date there is no published information on potential CCMs in Crocosphaera.

$\mathrm{C}, \mathrm{Fe}$, and Mo quotas and use efficiencies-Recently Fe requirements of both cultures and natural populations of Trichodesmium and lab cultures of the unicellular $\mathrm{N}_{2}$-fixers Crocosphaera and Cyanothece have been investigated (Kustka et al. 2003; Tuit et al. 2004; Berman-Frank et al. 2007). In general, these studies showed that $\mathrm{Fe}: \mathrm{C}$ ratios are correlated positively to Fe availability and negatively to cell size. The Fe: $\mathrm{C}$ ratios for Crocosphaera in our study ranged from 27 to $290 \mu \mathrm{mol} \mathrm{mol}^{-1}$ and varied with both $\mathrm{Fe}$ availability and (in Fe-replete cultures only) with $\mathrm{pCO}_{2}$. The minimum values we obtained for Crocosphaera in Felimited cultures were lower $\left(\sim 27 \mu \mathrm{mol} \mathrm{mol}{ }^{-1}\right)$ than the values (38 48 $\mu \mathrm{mol} \mathrm{mol}^{-1}$ ) from Kustka et al. (2003) and Berman-Frank et al. (2001) for Trichodesmium growing at the same rate of $\sim 0.1 \mathrm{~d}^{-1}$. Likewise, our estimation of net Fe use efficiency by Fe-limited Crocosphaera was 40-80\% higher than that of Fe-limited Trichodesmium at the same growth rate (Kustka et al. 2003). These results imply that this unicellular $\mathrm{N}_{2}$-fixer probably has a lower Fe requirement than does Trichodesmium, and it may therefore be less likely to be Fe limited in the open ocean.

Smaller cells with higher surface: volume ratios are in general less vulnerable to $\mathrm{Fe}$ limitation (Sunda and Huntsman 1997). The cell diameter of Crocosphaera is $\sim 3.0 \mu \mathrm{m}$, about threefold smaller than the cells of Trichodesmium. This would allow for higher growth rates of Crocosphaera in Fe-limited waters, as its higher surface:volume ratio would allow for a higher cell volume-normalized $\mathrm{Fe}$ uptake rate if $\mathrm{Fe}$ uptake per unit cell surface is constant at a given Fe concentration, as has been found previously (Sunda and Huntsman 1997). Thus, Crocosphaera should be able to out-compete Trichodesmium in Fe-limited waters in two ways, via higher uptake rates per unit of cell volume or biomass and lower $\mathrm{Fe}$ : C ratios needed to support growth. In addition, the fact that the former is unicellular and that the latter often forms large colonies likely affects their relative Fe uptake abilities and requirements as well.

The higher Fe quota of Trichodesmium may also be related to its differing $\mathrm{N}_{2}$ fixation strategy. As noted above, Trichodesmium fixes $\mathrm{N}_{2}$ only during the day, while Crocosphaera does so only in the dark (Tuit et al. 2004; BermanFrank et al. 2007). To protect its nitrogenase from inactivation by oxygen during photosynthesis, Trichodesmium is thought to depend upon elevated respiration rates, cytochrome oxidase activity, and/or antioxidant enzymes, all of which require Fe (Gallon 1992). The higher PSI : PSII ratios of Trichodesmium compared to unicellular diazotrophs (Berman-Frank et al. 2007; Milligan et al. 2007) may also tend to increase the $\mathrm{Fe}$ requirements of the former, since PSI has a sixfold higher Fe content than PSII (Strzepek and Harrison 2004).

Crocosphaera $\mathrm{Fe}: \mathrm{C}$ and Mo: $\mathrm{C}$ ratios determined by Tuit et al. (2004) varied on a diel basis and ranged from 7 to 97 and 0.45 to 0.90 , respectively, during the $\mathrm{N}_{2}$-fixing (dark) period. In general, the observed values from our culture study are considerably higher than their reports. Our lowest values of $\mathrm{Fe}: \mathrm{C}(\sim 27 \mu \mathrm{mol}: \mathrm{mol})$ and $\mathrm{Mo}: \mathrm{C}$ $(\sim 0.38 \mu \mathrm{mol}: \mathrm{mol})$ were obtained from the Fe-limited cultures; all of our sampling was carried out in the daytime.

Although we cannot provide a conclusive explanation for the difference in metal quotas obtained in our study and that of Tuit et al. (2004), the close correlations between our $\mathrm{Fe}: \mathrm{C}$ ratios and $\mathrm{Fe}$ availability, $\mathrm{N}_{2}$ fixation rates, and $\mathrm{pCO}_{2}$ (Figs. 2A, 5) indicate that our higher values are unlikely to be due to accidental $\mathrm{Fe}$ contamination of cultures or samples. Such contamination would inevitably result in a great deal of random variability between samples, obscuring the clear relationship between $\mathrm{Fe}$ quotas and the experimental variables. It is notable, though, that we have found that Crocosphaera cells are surprisingly resistant to lysis and acid digestion, and therefore cellular trace metals appear to be only incompletely extracted from filter samples by a typical short-term digestion protocol, as in Tuit et al. (2004). Our trace metal acid digest samples from this experiment were measured twice: once soon after digestion and a second time after allowing the samples to extract at room temperature for another 4 months. ICPMS-derived $\mathrm{Fe}$ and Mo values from the second analysis were two- or threefold higher than values from the first one; a similar comparison of digestion time effects on trace metal concentrations of eukaryotic phytoplankton samples shows an enhancement of only 20 $30 \%$ (data not shown). These results indicate that for Crocosphaera samples, extended acid digestion times may be required to avoid serious underestimation of trace metal quotas. Issues with incomplete acid digestion may also explain why our $\mathrm{Fe}: \mathrm{C}$ ratios for Crocosphaera are $\sim 36-$ fold higher than those reported by Berman-Frank et al. (2007) for another related unicellular diazotrophic cyanobacterium, Cyanothece.

Our study confirms and extends a growing body of evidence indicating that currently rising atmospheric $\mathrm{CO}_{2}$ levels will tend to significantly increase $\mathrm{N}_{2}$ fixation in tropical and subtropical marine ecosystems by the end of this century (Hutchins et al. 2007; Levitan et al. 2007; Ramos et al. 2007). Our culture studies predict that the relative magnitude of this increase may be somewhat greater for Trichodesmium (35-66\% increase; Hutchins et al. 2007) than for Crocosphaera ( $24 \%$; this study), but the general trend appears to be similar for both of these biogeochemically critical groups of globally distributed diazotrophs. This $\mathrm{CO}_{2}$ enhancement effect needs to be evaluated on several different timescales, including those that are relevant for plankton ecology (seasonal cycles of mixed-layer $\mathrm{pCO}_{2}$ ), anthropogenic global change (decadeand century-scale increases in atmospheric $\mathrm{pCO}_{2}$ ), and natural climatic cycles (glacial and interglacial $\mathrm{pCO}_{2}$ changes). The results of our experiments indicate that 
$\mathrm{CO}_{2}$ enrichment could alter new $\mathrm{N}$ inputs to the ocean by these two ecologically dominant groups on all of these timescales and that major feedbacks to not only $\mathrm{N}$ biogeochemistry but also to the $\mathrm{C}, \mathrm{P}$, and Fe cycles are to be expected. This study highlights some of these potential interactive feedbacks between $\mathrm{pCO}_{2}, \mathrm{~N}_{2}$ fixation, and $\mathrm{Fe}$ availability.

Unlike the predictable trend of rising $\mathrm{pCO}_{2}$, the possible future trends in $\mathrm{Fe}$ supplies to the oceans are relatively unknown. Some studies have predicted climate-driven reductions in aeolian Fe inputs (Mahowald and Luo 2003), while others suggest that $\mathrm{Fe}$ supplies could increase to parts of the open ocean as a result of either accelerating humaninduced desertification or of deposition of anthropogenic fossil fuel aerosols (Sedwick et al. 2007). Predicted increased stratification and mixed-layer shoaling may also lead to reduced supplies of $\mathrm{Fe}$ from vertical advection and mixing (Boyd and Doney 2002). Our results and those of Hutchins et al. (2007) indicate that increasing $\mathrm{pCO}_{2}$ and consequent stimulation of $\mathrm{N}_{2}$ fixation may increase the potential for $\mathrm{Fe}$ and $\mathrm{P}$ limitation of diazotrophs in particular, and of the whole biological community in general, throughout the oligotrophic ocean. Fe limitation in particular seems to have the potential to constrain future $\mathrm{CO}_{2}$-mediated increases in oceanic diazotrophy, unless changing climate regimes are also accompanied by enhanced $\mathrm{Fe}$ supplies. Under such hypothetical future conditions, warmer, dust-fertilized and $\mathrm{CO}_{2}$ enriched, $\mathrm{N}_{2}$-fixing cyanobacteria appear likely to thrive and could ultimately drive major regime shifts in the gyre ecosystems.

It is becoming obvious that other environmental factors, such as temperature, light, and Fe and nutrient availability, can interactively modify growth and $\mathrm{N}_{2}$ fixation responses to changing $\mathrm{pCO}_{2}$. These interactive effects need to be carefully considered in designing and interpreting experiments and models aimed at determining rising $\mathrm{pCO}_{2}$ effects on natural populations of phytoplankton. Future work focused on these combined effects will help us to build a much more complete picture of the intricate web of feedback interactions among elevated $\mathrm{pCO}_{2}$, other global change processes, and the biogeochemistry and biology of the ocean.

\section{References}

Badger, M. R., G. D. Price, B. M. Long, and F. J. Woodger. 2006. The environmental plasticity and ecological genomics of the cyanobacterial $\mathrm{CO}_{2}$ concentrating mechanism. J. Exp. Bot. 57: 249-265.

Bell, P. R. F., And F.-X. Fu. 2005. Effect of light on growth, pigmentation and $\mathrm{N}_{2}$ fixation of cultured Trichodesmium sp. from the Great Barrier Reef lagoon. Hydrobiologia 543: 25-35.

Berman-Frank, I., J. T. Cullen, Y. Shaked, R. M. Sherrell, AND P. G. FAlKowsKi. 2001. Iron availability, cellular iron quotas, and nitrogen fixation in Trichodesmium. Limnol. Oceanogr. 46: 1249-1260.

A. Quigg, Z. V. Finkel, A. J. Irwin, and L. Haramaty. 2007. Nitrogen-fixation strategies and $\mathrm{Fe}$ requirements in cyanobacteria. Limnol. Oceanogr. 52: 2260-2269.

Bopp, L., others. 2001. Potential impact of climate change on marine export production. Glob. Biogeochem. Cycles 15: 81-99.
Boyd, P. W., And S. C. Doney. 2002. Modeling regional responses by marine pelagic ecosystems to global climate change. Geophys. Res. Lett. 29: 1806, doi:10.1029/2001GL014130.

Burkhardt, S., G. Amoroso, U. Riebesell, and D. Sültemeyer. 2001. $\mathrm{CO}_{2}$ and $\mathrm{HCO}_{3}-$ uptake in marine diatoms acclimated to different $\mathrm{CO}_{2}$ concentrations. Limnol. Oceanogr. 46: 1378-1391.

— AND U. RIEBESELL. 1997. $\mathrm{CO}_{2}$ availability affects elemental composition $(\mathrm{C}: \mathrm{N}: \mathrm{P})$ of the marine diatom Skeletonema costatum. Mar. Ecol. Prog. Ser. 155: 67-76.

- - AND I. ZONDERVAN. 1999. Effects of growth rate, $\mathrm{CO}_{2}$ concentration, and cell size on the stable carbon isotope fractions in marine phytoplankton. Geochim. Cosmochim. Acta 63: 3729-3741.

Capone, D. G., J. P. Zehr, H. W. Paerl, B. Bergman, and E. J. CARPEnter. 1997. Trichodesmium, a globally significant marine cyanobacterium. Science 276: 1221-1229.

Dyhrman, S. T., and S. T. Haley. 2006. Phosphorus scavenging in the unicellular marine diazotroph Crocosphaera watsonii. Appl. Environ. Microbiol. 72: 1452-1458.

Falcon, L. I., S. Pluvinage, and E. J. Carpenter. 2005. Growth kinetics of marine unicellular $\mathrm{N}_{2}$-fixing cyanobacterial isolates in continuous culture in relation to phosphorus and temperature. Mar. Ecol. Prog. Ser. 285: 3-9.

Feng, Y., M. E. Warner, Y. Zhang, J. Sun, F.-X. Fu, and D. A. Hutchins. 2008. Interactive effects of increased $\mathrm{pCO}_{2}$, temperature and irradiance on the marine coccolithophore Emiliania huxleyi (Prymnesiophyceae). Eur. J. Phycol. 43: 87-98.

Frew, R. D., AND OTHers. 2006. Particulate iron dynamics during $\mathrm{Fe}$ cycle in subantarctic waters southeast of New Zealand. Glob. Biogeochem. Cycles 20: GB1S93, doi:10.1029/ 2005GB002558.

Fu, F.-X., And P. R. F. Bell. 2003. Growth, $\mathrm{N}_{2}$ fixation and photosynthesis in a cyanobacterium, Trichodesmium sp., under Fe stress. Biol. Lett. 25: 645-649.

- M. E. Warner, Y. Zhang, Y. Feng, and D. A. Hutchins. 2007. Effects of increased temperature and $\mathrm{CO}_{2}$ on photosynthesis, growth and elemental ratios of marine Synechococcus and Prochlorococcus (Cyanobacteria). J. Phycol. 43: 485-496.

- Y. Zhang, P. R. F. Bell, and D. A. Hutchins. $2005 a$. Phosphate uptake and growth kinetics of Trichodesmium (Cyanobacteria) isolates from the North Atlantic Ocean and Great Barrier Reef, Australia. J. Phycol. 41: 62-73.

,-- K. Leblanc, S. A. Sanudo-Wilhelmy, and D. A. Hutchins. 2005 b. The biological and biogeochemical consequences of phosphate scavenging onto phytoplankton cell surfaces. Limnol. Oceanogr. 50: 1459-1472.

- - M. E. Warner, Y. Feng, J. Sun, and D. A. Hutchins. 2008. A comparison of future increased $\mathrm{CO}_{2}$ and temperature effects on sympatric Heterosigma akashiwo and Prorocentrum minimum. Harmful Algae 7: 76-90.

Gallon, J. R. 1992. Reconciling the incompatible: $\mathrm{N}_{2}$ fixation and oxygen. New Phytol. 122: 571-609.

Gordillo, F. J. L., C. Jimenez, F. L. Figueroa, and F. X. Niell. 2003. Influence of elevated $\mathrm{CO}_{2}$ and nitrogen supply on the carbon assimilation performance and cell composition of the unicellular alga Dunaliella viridis. Physiol. Plant 119: 513-518.

Hare, C. E., AND others. 2007. Consequences of increased temperature and $\mathrm{CO}_{2}$ for algal community structure in the Bering Sea. Mar. Ecol. Prog. Ser. 352: 9-16.

Hein, M., And K. SAnd-Jensen. 1997. $\mathrm{CO}_{2}$ increases oceanic primary production. Nature 388: 526-527.

Hutchins, D. A., G. R. Ditullio, Y. Zhang, and K. W. BRULAND. 1998. An iron limitation mosaic in the California coastal upwelling regime. Limnol. Oceanogr. 43: 1037-1054. 
AND OTHERs. 2007. $\mathrm{CO}_{2}$ control of Trichodesmium $\mathrm{N}_{2}$ fixation, photosynthesis, growth rates, and elemental ratios: Implications for past, present and future ocean biogeochemistry. Limnol. Oceanogr. 52: 1293-1304.

Intergovernmental Panel on Climate Change (IPCC). 2007. Fourth assessment report: climate change 2007 [Internet]. Available from http://www.ipcc.ch/pdf/assessment-report/ar4/ syr/ar4_syr.pdf

KIM, J.-M., AND OTHERS. 2006. The effect of seawater $\mathrm{CO}_{2}$ concentration on growth of a natural phytoplankton assemblage in a controlled mesocosm experiment. Limnol. Oceanogr. 51: 1629-1636.

Kustika, A. B., S. A. Sanudo-Wilhelmy, E. J. Carpenter, D. Capone, J. Burns, And W. G. Sunda. 2003. Iron requirement for dinitrogen- and ammonium-supported growth in cultures of Trichodesmium (IMS 101): Comparison with nitrogen fixation rates and iron: carbon ratios of field populations. Limnol. Oceanogr. 48: 1869-1884.

Levitan, O., AND OTHERs. 2007. Elevated $\mathrm{CO}_{2}$ enhances nitrogen fixation and growth in the marine cyanobacterium Trichodesmium. Glob. Change Biol. 13: 531-538.

Mahowald, N. M., And C. Luo. 2003. A less dusty future? Geophys. Res. Lett. 30: 1903, doi:10.1029/2003GL017880.

Milligan, A. J., I. Berman-Frank, Y. Gerchman, G. C. Dismukes, AND P. G. Falkowski. 2007. Light-dependent oxygen consumption in nitrogen-fixing cyanobacteria plays a key role in nitrogenase protection. J. Phycol. 43: 845-852.

Mills, M. M., C. Ridame, M. Davey, J. Laroche, and R. J. GEIDER. 2004. Iron and phosphorus co-limit nitrogen fixation in the eastern tropical North Atlantic. Nature 429: 292-294.

Montoya, J. P., C. M. Holl, J. P. Zehr, A. Hansen, T. A. Villareal, and D. G. Capone. 2004. High rates of $\mathrm{N}_{2}$ fixation by unicellular diazotrophs in the oligotrophic Pacific Ocean. Nature 430: 1027-1031.

Morel, F. M. M., J. G. Rueter, D. M. Anderson, and R. R. L. Guillard. 1979. Aquil: A chemically defined phytoplankton culture medium for trace metal studies. J. Phycol. 15: $135-141$.

Mulholland, M. R. 2007. The fate of nitrogen fixed by diazotrophs in the ocean. Biogeosciences 4: 37-51.

- ANd P. W. Bernhardt. 2005. The effect of growth rate, phosphorus concentration, and temperature on $\mathrm{N}_{2}$ fixation, carbon fixation, and nitrogen release in continuous cultures of Trichodesmium. Limnol. Oceanogr. 50: 839-849.

Müller, C., W. Reuter, W. Wehrmeyer, H. Dau, and H. SENGER. 1993. Adaptation of the photosynthetic apparatus of Anacystis nidulans to irradiance and $\mathrm{CO}_{2}$-concentration. Bot. Acta 106: $480-487$.

Petit, J. R., AND others. 1999. Climate and atmospheric history of the past 420,000 years from the Vostok ice core, Antarctica. Nature 399: 429-436.

Platt, T., C. L. Gallegos, and W. G. Harrison. 1980. Photoinhibition of photosynthesis in natural assemblages of marine phytoplankton. J. Mar. Res. 38: 687-701.

Ramos, J. B. E., H. Biswas, K. G. Schulz, J. Laroche, and U. RIEBESELL. 2007. Effect of rising atmospheric carbon dioxide on the marine nitrogen fixer Trichodesmium. Glob. Biogeochem. Cycles 21: GB2028, doi:10.1029/2006GB002898.

Raven, J. A. 1997. Inorganic carbon acquisition by marine autotrophs. Adv. Bot. Res. 27: 85-209.
, M. C. W. Evans, And R. E. Korb. 1999. The role of trace metals in photosynthetic electron transport in $\mathrm{O}_{2}$-evolving organisms. Photosynth. Res. 60: 111-149.

Rueter, J. G., K. Ohki, And Y. Fujita. 1990. The effect of iron nutrition on photosynthesis and nitrogen fixation in cultures of Trichodesmium (Cyanophyceae). J. Phycol. 30: 935-942.

Sandmann, G. 1985. Consequences of iron deficiency on photosynthetic and respiratory electron transport in bluegreen algae. Photosynth. Res. 6: 261-271.

SAÑUdo-Wilhelmy, S. A., AND OTHERs. 2001. Phosphorous limitation of nitrogen fixation by Trichodesmium in the central Atlantic Ocean. Nature 411: 66-69.

SARmiento, J. L., AND Others. 2004. Response of ocean ecosystems to climate warming. Glob. Biogeochem. Cycles 18: GB 3003, doi:10.1029/2003GB002134.

Sedwick, P. N., E. R. Sholkovitz, and T. M. Church. 2007. Impact of anthropogenic combustion emissions on the fractional solubility of aerosol iron: Evidence from the Sargasso Sea. Geochem. Geophys. Geosyst. 8: Q10Q06, doi:10.1029/2007GC001586.

StrzepeK, R. F., and P. J. Harrison. 2004. Photosynthetic architecture differs in coastal and oceanic diatoms. Nature 431: 689-692.

Sunda, W. G., And S. A. Huntsman. 1995. Iron uptake and growth limitation in oceanic and coastal phytoplankton. Mar. Chem. 50: 189-206.

, AND - 1997. Interrelated influence of iron, light and cell size on marine phytoplankton growth. Nature 390: 389-392.

Takeda, S., And A. Tsuda. 2005. An in situ iron-enrichment in the western subarctic Pacific (SEEDS): Introduction and summary. Prog. Oceanogr. 64: 95-109.

Tortell, P. D., G. R. Ditullio, D. M. Sigman, and F. M. M. Morel. 2002. $\mathrm{CO}_{2}$ effects on taxonomic composition and nutrient utilization in an Equatorial Pacific phytoplankton assemblage. Mar. Ecol. Prog. Ser. 236: 37-43.

, G. H. RAU, AND F. M. M. Morel. 2000. Inorganic carbon acquisition in coastal Pacific phytoplankton communities. Limnol. Oceanogr. 45: 1485-1500.

Trick, C. G., S. W. Wilhelm, AND C. M. Brown. 1995 Alterations in cell pigmentation, protein expression, and photosynthetic capacity of the cyanobacterium Oscillatoria tenuis grown under low iron conditions. Can. J. Microbiol. 41: $1117-1123$.

Tuit, C., J. Waterbury, and G. Ravizza. 2004. Diel variation of molybdenum and iron in marine diazotrophic cyanobacteria. Limnol. Oceanogr. 49: 978-990.

Wyman, M. 1992. An in vivo method for the estimation of phycoerythrin concentration in marine cyanobacteria (Synechococcus spp.). Limnol. Oceanogr. 37: 1300-1306.

ZAR, J. H. 1999. Two-factor analysis of variance, 206-235. In J. H. Zar [ed.], Biostatistical analysis. Prentice-Hall.

Zehr, J. P., S. R. Bench, E. A. Mondragon, J. McCarren, and E. A. Delong. 2007. Low genomic diversity in tropical oceanic $\mathrm{N}_{2}$-fixing cyanobacteria. Proc. Natl. Acad. Sci. USA 104: $17807-17812$.
Received: 12 November 2007 Accepted: 22 June 2008 Amended: 8 July 2008 